造わ数々これ熋民あ

機の機のをれ花・か造 能検能結、わに小え 分討要果科れよ室な機 析に件学はる直い能 はよを構理、社樹な分 る仮造論こ会のど析 不々設年での構三のは 適、乙機あ三造者批 当こた能れ者のは判の でれ場分ばの評、に气 あら合析当見価初さ气 りのにに然解・期ら‡ 、問整はみの制のさむ 社題合、たう御批れ苞 会に的こされし判た题 理こなれな論た議まけ立骨解わら

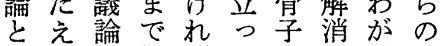
しる検ばてと守国ア て構 行討な、するの1 採造なさら構る方学デ 用、以れな造も向界ア で機うてい1 のでもか き能るい諸機と独号 な分かな規能み自構出 い析、以準分なの造発 とはま致々析す洗玄し 結原命点練機た 論原、的照了でを能 す理社ならイ、加分こ る上存構閴あ站者え析の 在造势わを学議い人 しのいせ理兒論ちデ え変くて想解をはア な動つみ的は大やは い法もたに一きく粗 。則存。具致く導削 そ索在現し前入り れぞ守して進しで ゆのるたいさた末 によこ・无るせ方整 にがルをな わ遒、を杂文 れ出明、り以こ わ守 ら組わ来乃 れるかけ け唯 は尘な構と多 ななる。相富社 导でた そ機富社 的市 分健変 以るえ

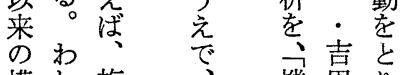
構机複

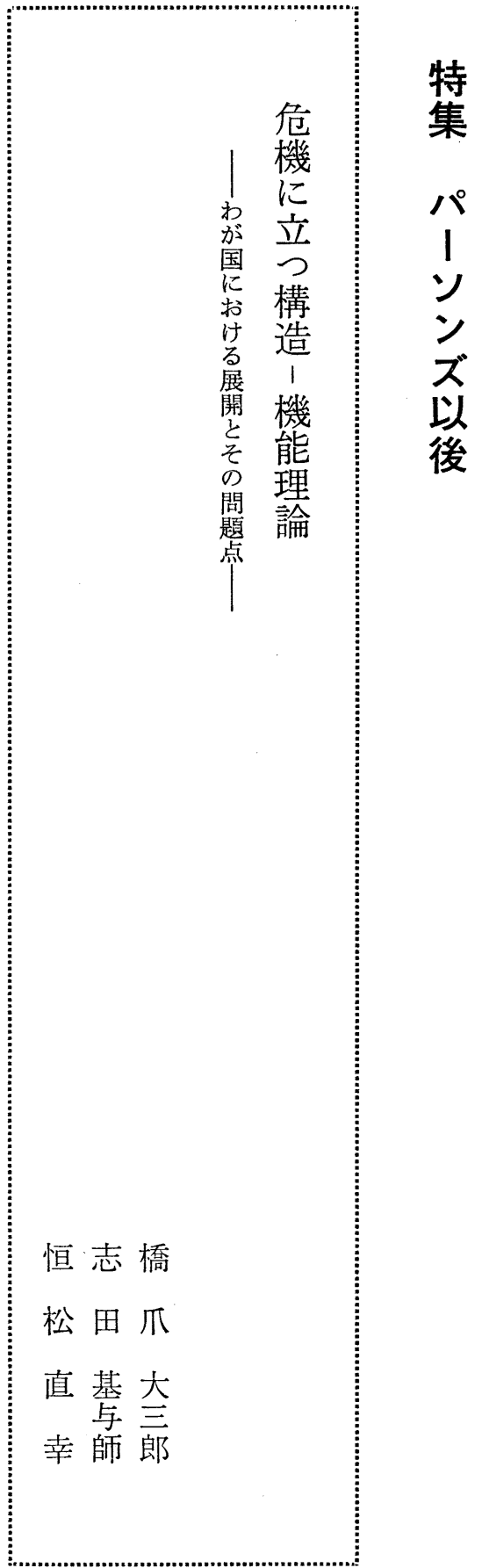




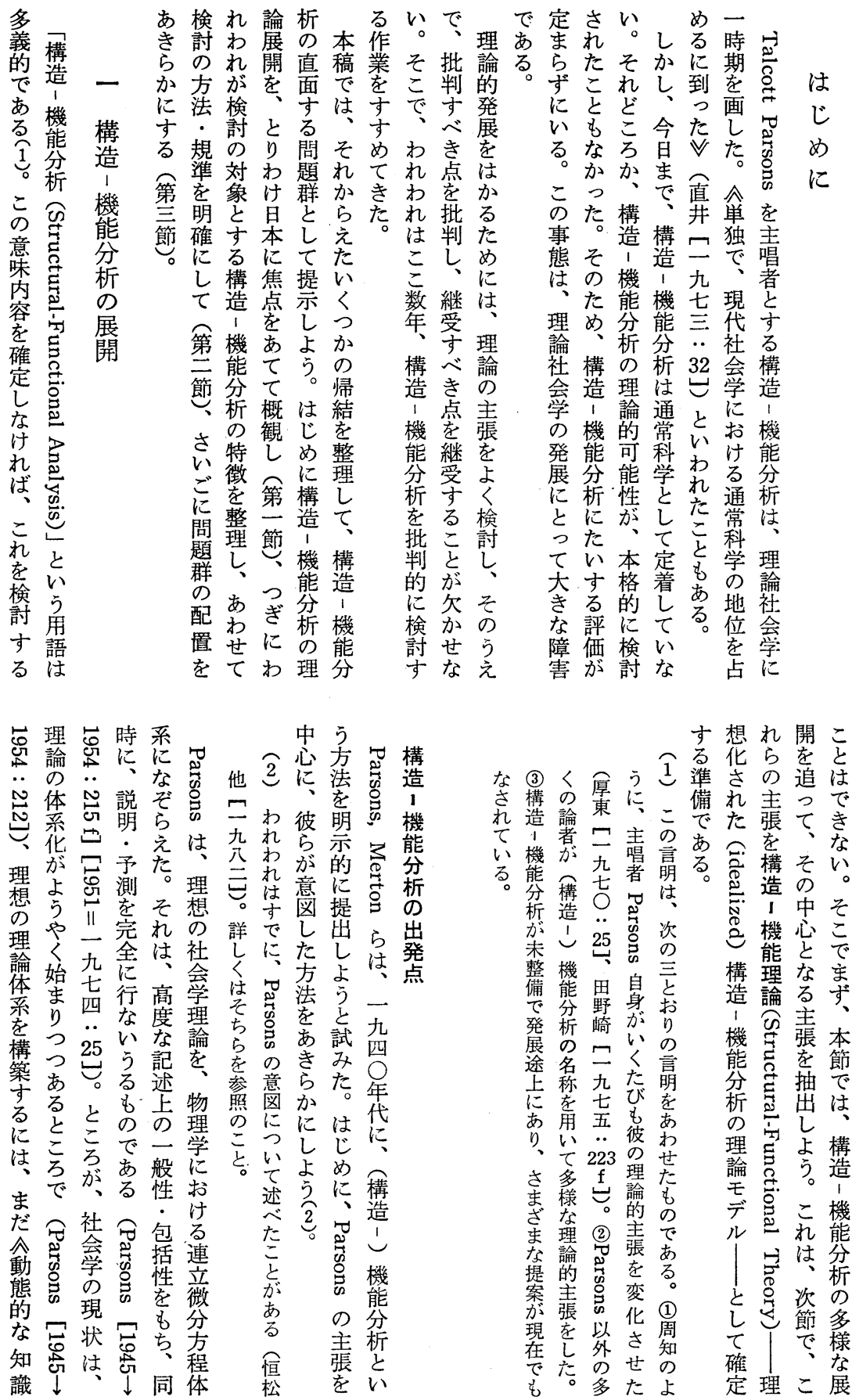

$35(1 \cdot 3) 3$ 社会学評論 
構係の官

造㤎構恕こ 以問造 当題の の 概 九

諸な念九に

変る弆四完

数。角 四全

の 董芯 る 26 な

重要るき 告

性はこと連

はこれて理

かこと、論

るに残いに

規 りった

準機のたい

で能変んす

あ の数静る

る概・態令

。念利態众

そ導用な善

ら人方理

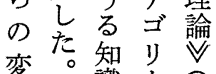

変。知 リ

は数能
記 ॥にある 社こる、苫 述一よる高会々た 概九つ、官学にほ構 で忩て判は論意—造 あ 3 㻎 1 現た系にうな妥。 8 現彼二妥。党学 官尖は般す产では

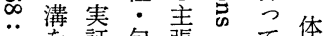

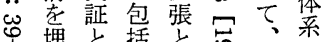
Nめ の性老它行の る。接怙、出為 $\overrightarrow{n_{2}}$ そき合社なは論性 定で学会き理具知 官る考学り 論、体知

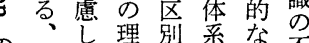
のと場と論し別系構足 合主、にて般成足 吕る中といにに関の 社範ている関特間

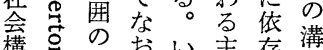
構 理おい主存瑇垂 造灾論荷ぽ 熏な 埋

化洗定る 的拠

を゙練数。知枠そ るれれでいた的 シたなに不孛やたこで

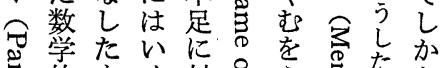
的むく対。另官理な 永のつ処官市す想以

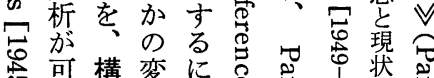

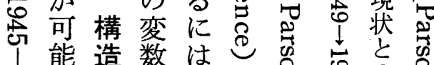

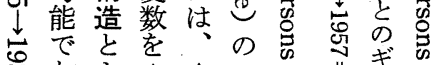

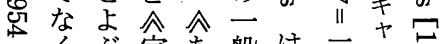
‥く定あ般は二数空

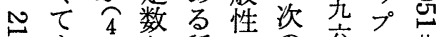
。

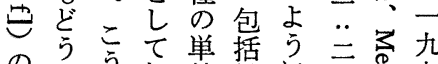

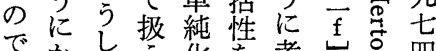
加气う化を考山四 あ扱てしの保えらや

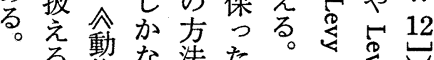
る態な法た理灾岕

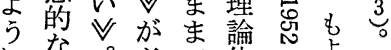
に問こ必で体 単題こ要㗢 系 芯認 純を筷であ態準。識

あが機い命食怘的食

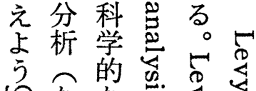
合な な 怘这 岁 。い説しひ官

し奛は、㲾

果成目構

分功的造尚

析さ論機は

によ导能は

最う赏要こ

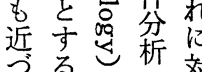

い努を㔖し

た構できする

造ある篝は

1つ限䓌?

機た

分これ 除号 警

のは試を怘索

み相こ若ら

だ互 連で壳て

一る

六 と矛怘、幅 機

二考客六觉精昘能

18 定查 ... 沓分透論

f、しも 9 冢析考 の

42 小名を它人也想

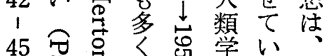

45 穴

た物理の .

皇有譏の

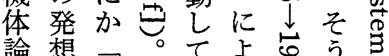

論想 ᄀ。てよ学うる

に亡有こいれ怘での

い接機こる゙ば 芯な維

ひ続体で全、機 忍な持

てるの体体能导な

は 5 方傃采の。逆

素点向系の 概 機く

朴し 加状念能

なしすが態は 的発

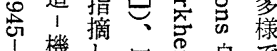

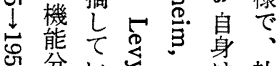

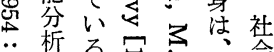

氙

源 $\quad$ 品造 学

也泉

的し光当を令

論、い初準来

論そる。集来

とここ連と的

近は 引立 る 的

乙 構て程 す な

々牲 やの機諸

有了四分野

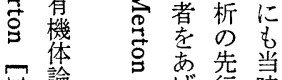

灾論 导京先当

し造彼式怘の

ま 1 の体。゙

う機議系名で る るら 危態論か怘あ ば 険分析号导り、灾機 


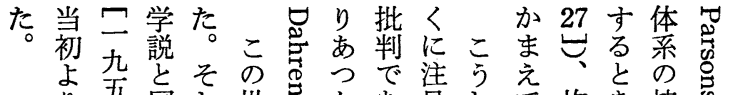

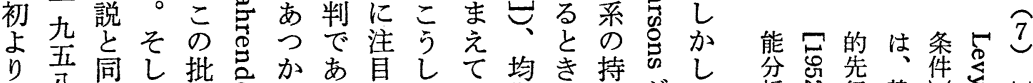

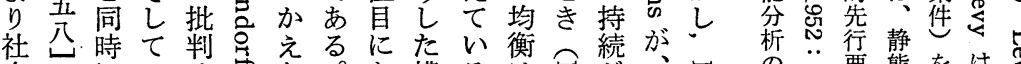

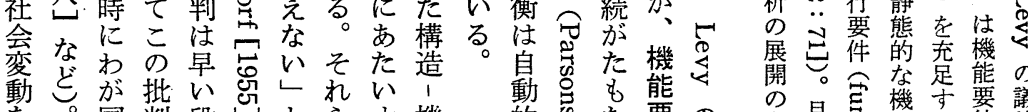
老。国判段怘と号す機 いそには階卡はる能 かれ丹务员端の分 にゅ念パら市\&的は析

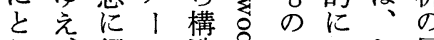
り紹ソ造员でいわ展 あわ介ン、すあっが開 つがさズ機炰めてて国に か国れを能导っ二の対 らにれは分、た構議し かおた心析导造論て をけ不め批导た造を 問る垍と判灾と機天批 題構入守の品隹能き判

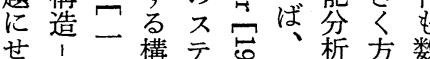
ぜ機九造吕总析方数 る能五1夕曲社う人 を分八機 1 必会け現 え析谷能 $7^{\circ}$ な家穴とな无動初た か注富晳な已出㤎期と

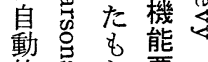

的兒た數の

に最机晔警 㻅論垔 は

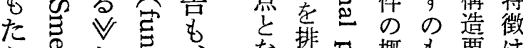

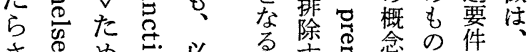

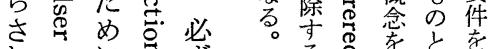
れ纪ず る实必它し 专... 共 る穴た 有 ॥す苍の 機一べを 体九きを解 論五条公 の八件体は 落 /で系な と一あのら し九る均な 穴五、衡少 が九となっ 待 I 定いた

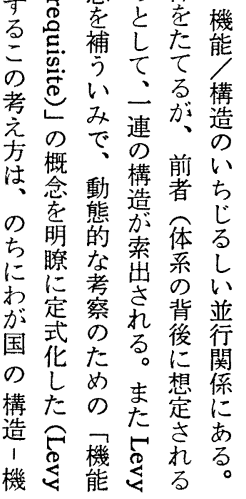

る芑. 補と壳機

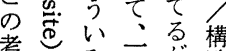
え亲架連が造 法念動構前 の老態造者じ ち明的架体る に瞭な悉系し 热定趂尜背並 国式のる後行 のしめ想保 構たのな定に 機导機莡杂る
じ

る,九 行六れる、苗五口森

こ 仓

発以心九化孝字西五吾忘

展降い五に社机云五ば

ににる貢な薖が九五田武

献るならな程ぎ吾亲野田

しとたたしで岕崎二

た吾めての塩二杂

の構公別占例野入厹五

は造 は途え外野五五

富機学検見云五茥

永能説詥解新五空作沢

健分理㤎で明志田口

一析 解必要るこ茿藤九

吉わ閶あこ旮灾藤五五

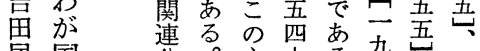

氐国独野ま張方。五二斉

人独野ま張二。亲二蚉

小息

室 発

直 展

のは
貝富稿交鈴吾厹

り二わに

忘杂わお
再自批しめる

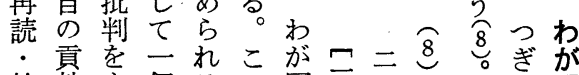

検献 個るの国云

詂をあの。時に兄 173 日

につわっ（i）期構○不

あけせ機包造 .. 193 に

た加て能芯現 147 がお

いえ受主导れ機卢詳る

すな容義にた能をし構

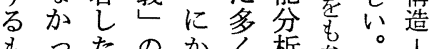

むつたの㔔析参。1

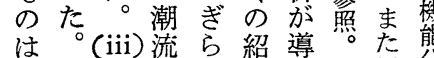

少そ忠とす仝

なれ実し、論さ

いゆなてい文れ

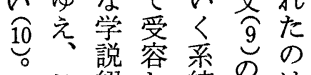

こ紹し統の特

の時でたも待

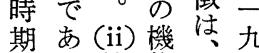

のろ機能 次五

文と主論年

でし義を点前

今㔔詨全に後

\&独るととあ

野应

愛 機
能展

編忩分開

䄷析

二史更

九 こ 展

わお

がけ

国る

に構

お造

计

構能

造 分

開

吾い泟

て

齐菜市

表表秒 概

田 観

野九 ᄂ

崎七よ 


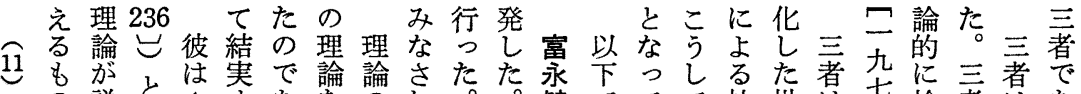

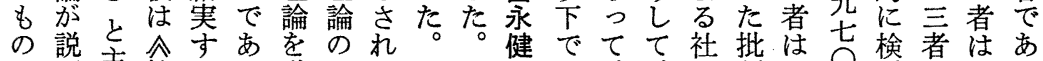

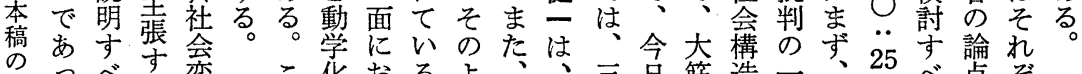

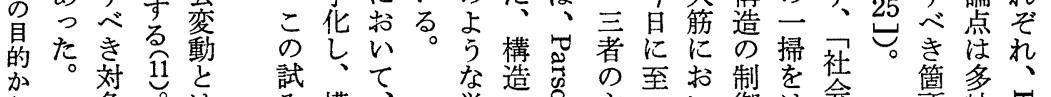

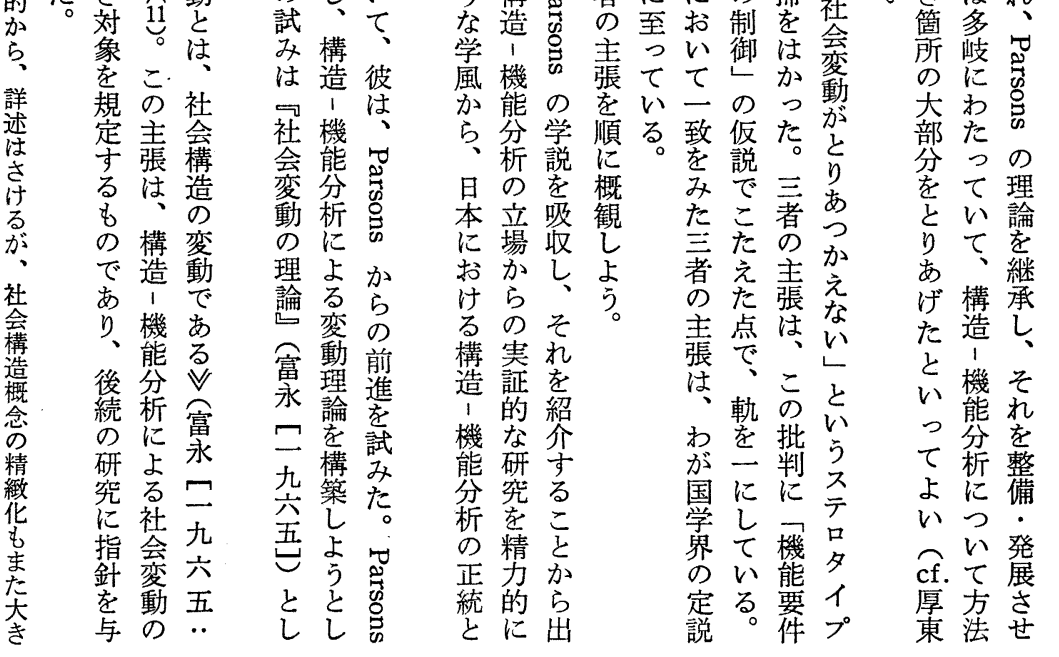

彫六を支

环 四、構吉

た 41 造 は

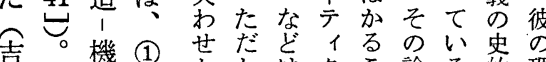

田と能相加し注ク論る的理

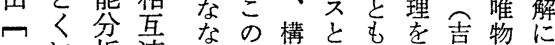

九後椞関い陚造ので明早論占

六者 本 分

三㤎質析

二要規あ

九 定る

六特 寸

忩徵 る (2)

三でへ機

ロあ吉能

二る田要

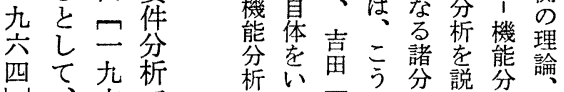

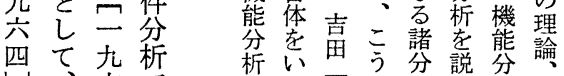

$\underbrace{}_{0}$ 六で

機 三

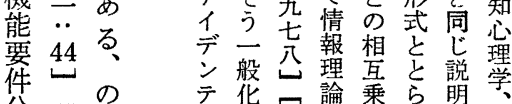

分 $ロ$ テ华ロ論乗ら明学

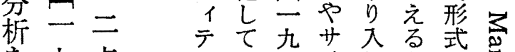

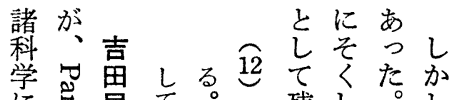
に苞氐六相こ残しなし、業

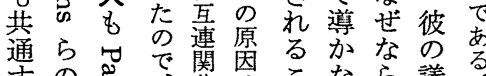
寸のまで閧因こなら議る。

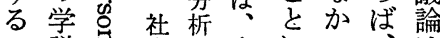
般にを説念変側富なたた社は 的之手動面口っ会構 ならが孛を強九艻構造 説わか説強九。造 琞れり势調空吾紊機 形るとるる正変能 式こし要わに市動分 と元因りお方法析 理な出をにけ社則の 解く発措機構社念変 寺 、発定機構㚆、動 る構たき熊造変構理 に造っな件耭造論 た機吉㚙分能則機し た機田た梠分析の機し た分二な側の構熋を 13 析九で面規築析不 は年十 課論分 題理 で 


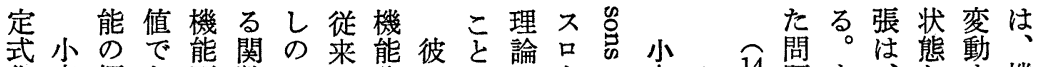
化室概あ要数よあ分はがを! か室行售閴も態動機の しの念る件型いい析、形が古直彼をる能努 たもここの法もまを経彼式ン樹吉たなとのさと要力

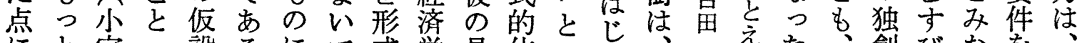

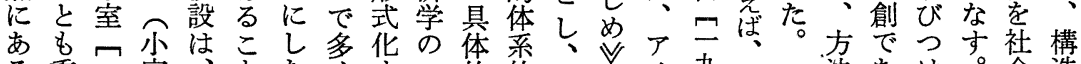

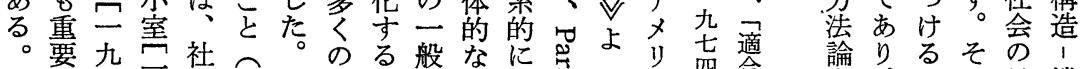

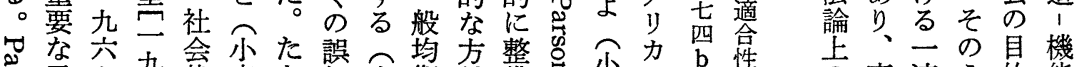

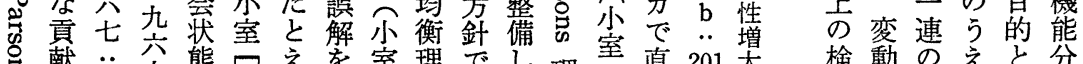
总 献六態吕を室理でし理室直 201 篹検動のえと分

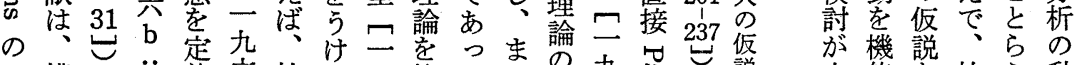

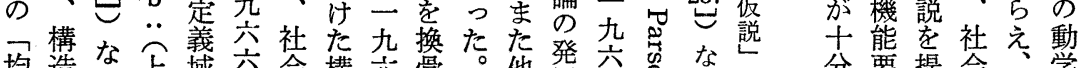

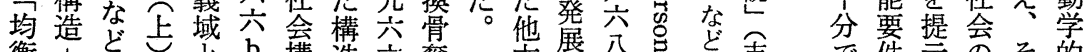

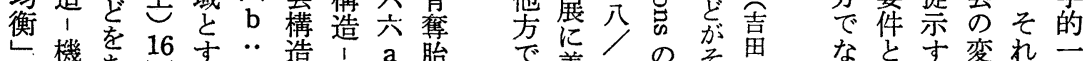
は機劣 16 す

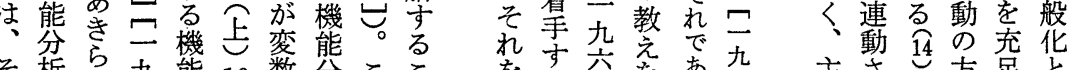

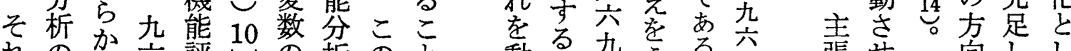

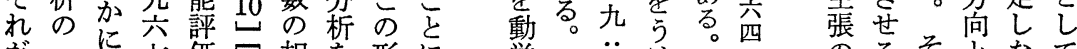
がつに七価二相を形に学—

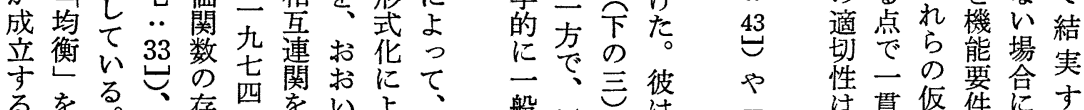

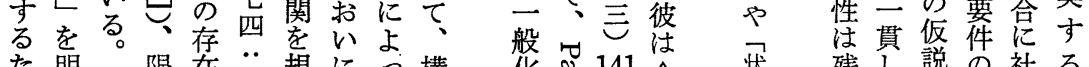
た明 限在 $\ddot{58}$ 規にう構 华芯 141 余 状 残し説の社る

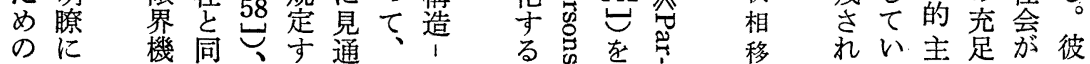

にる続動構維機造 .. のシシ シすの条

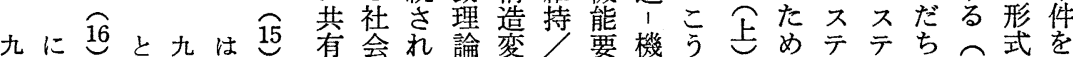

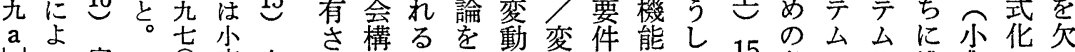

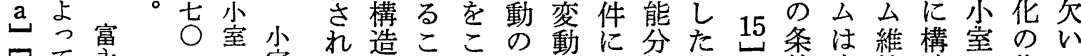
二て永第口室る版るらの方行少定口件変持造口作て 九行口第二去版に制に定向のると式二を動へ1二業い

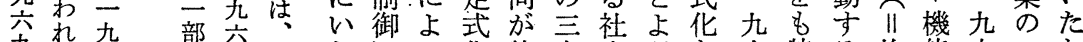

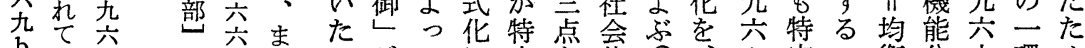

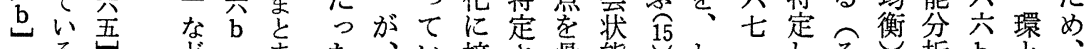

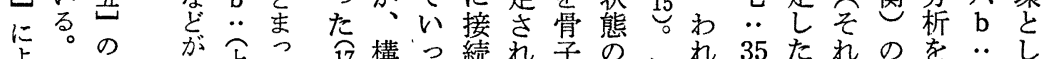

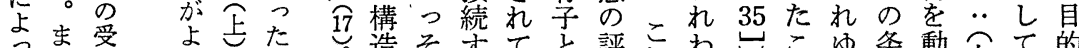

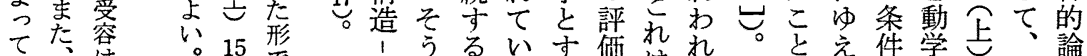

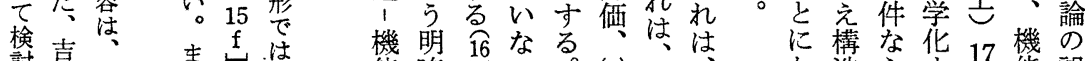

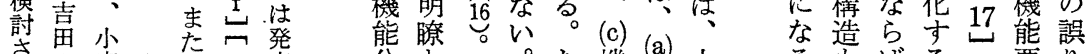

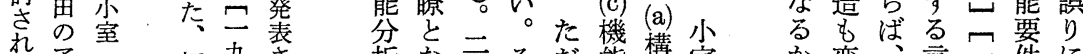

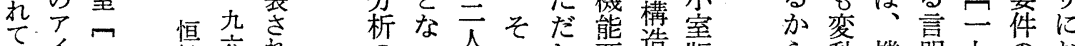

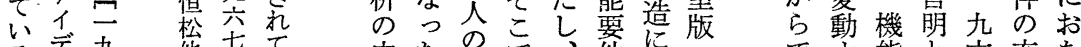

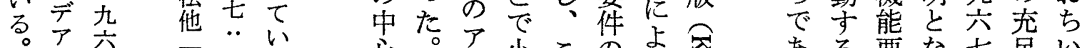

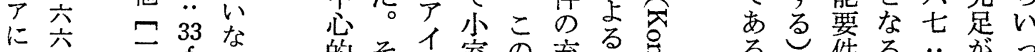

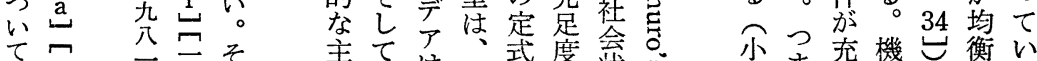

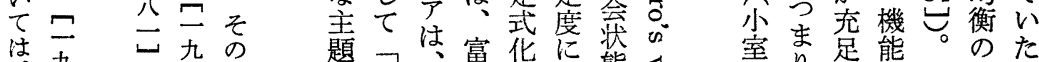

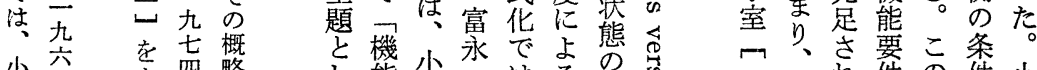

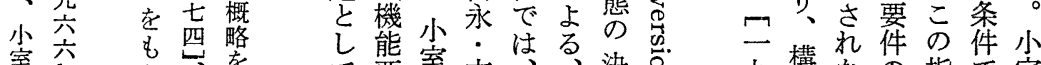

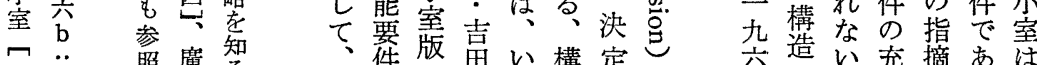
二

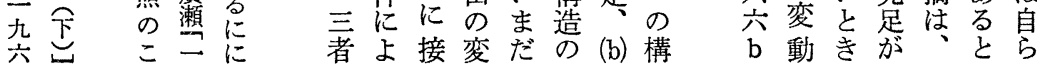


図 1 構造 - 機能理論の骨格

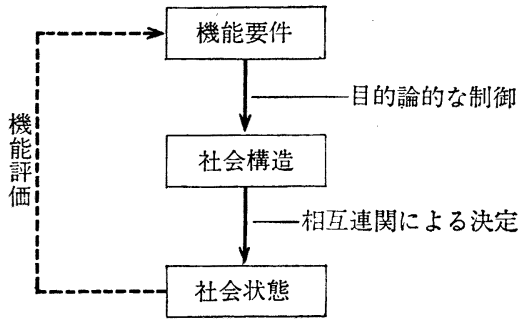

の発㓊

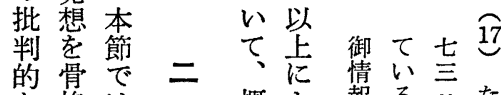

な格は、構 概よ観り る

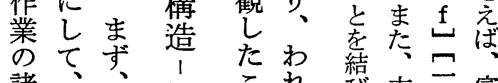
諸構前機とれわ繥吉富 準造節能に机至号 を1で理なはるる艺艺 ら能らの。構卡四な二 か理か 批造方

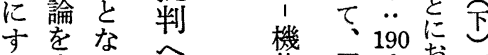
る定っ 能同 $f$ 怙 74

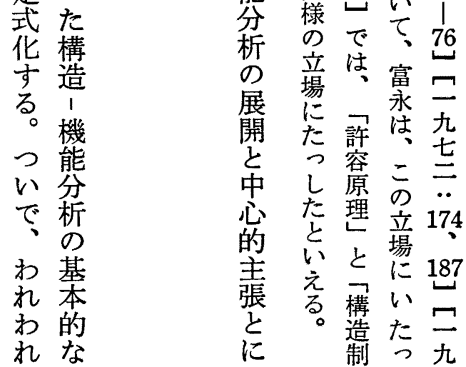

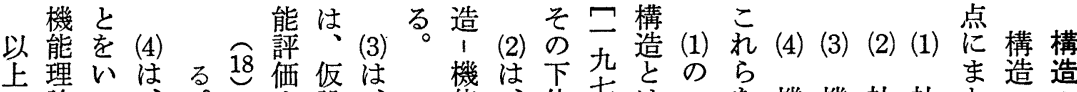

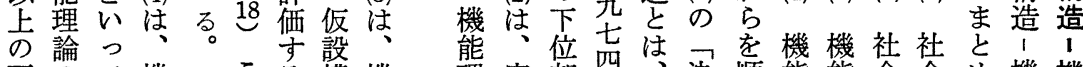

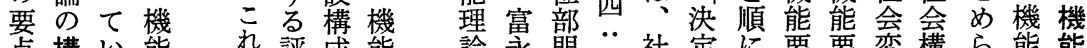
点構い能爰評能論永門 $\ddot{58}$ 社定に要要変構ら能能

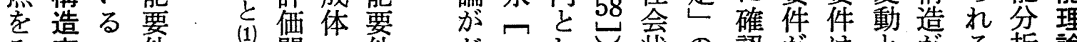

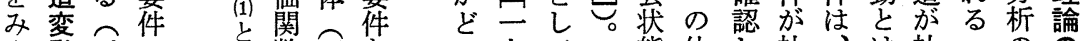

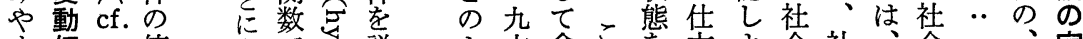

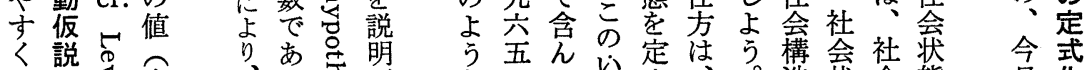

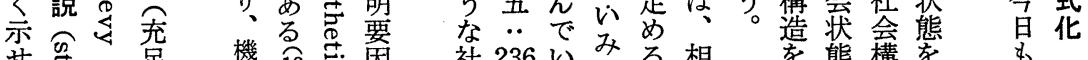
ば穷官是 図节 N $1 \stackrel{\sigma^{2}}{\text { 社 }}$ の总 莺 会

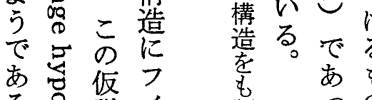

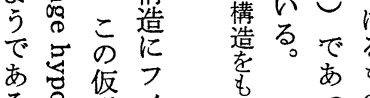
万芦説 1

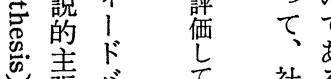
と㲀 バ う。構省 造る に等要 機 要 社 236 いる゙る相態構を 会がる。湾連 動 明 示

説 的

明に

る 主

の し

加た

をも

特で

定 あ

しる。

い構
構㦁㦁 造方炃

機程析

能式の

理 組 組

は、に 相想よ 互当守て 埆るい

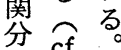
析 小社 を室会
制学造決告

御機 の定 于能変守 る。評動る。 るす \& c 㸓
光
考
え
势
る
羕
は
次
の
4 


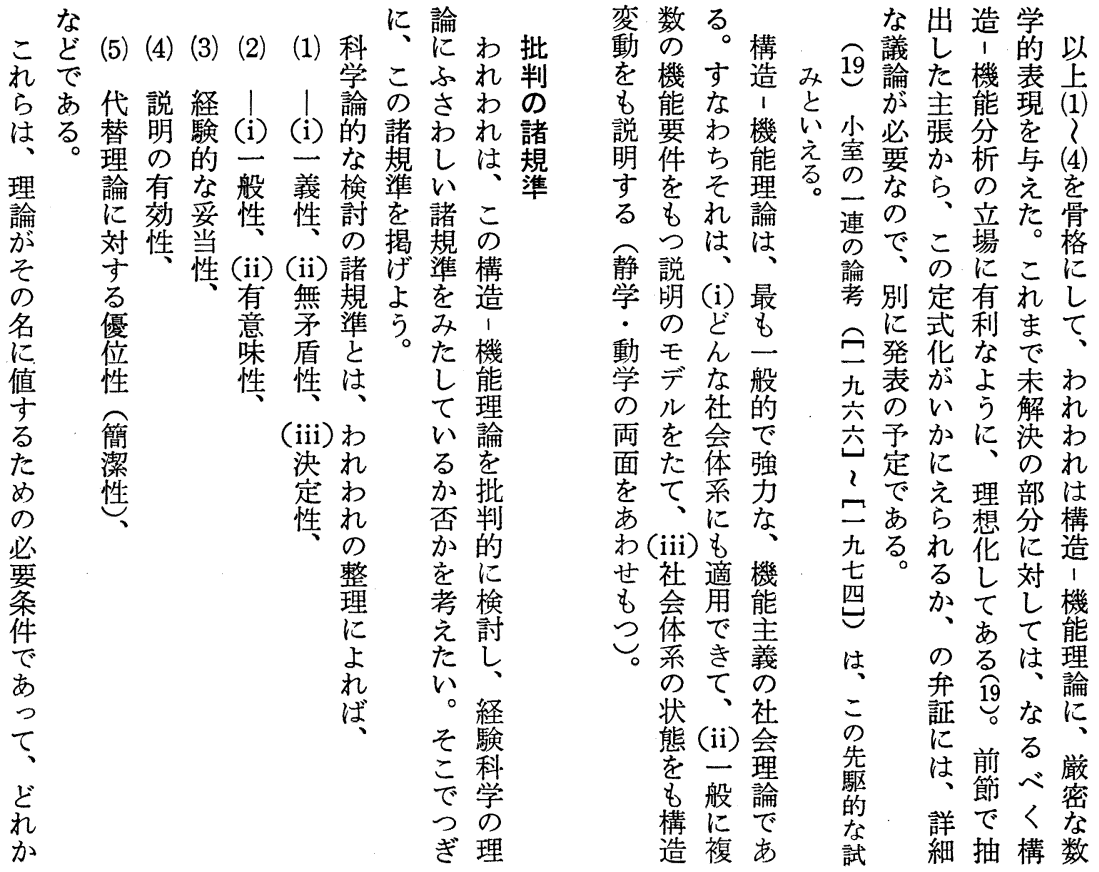

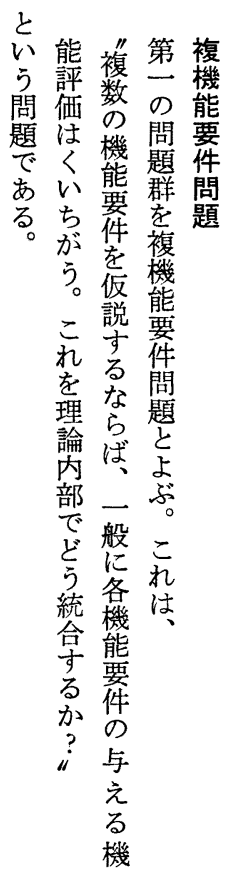

造で複構題論らと䄈 変りの造. 配え問構節 動、機、置て題造で を第能機をいの、 あ 説三要能確るう機た 明は件理認。ち能え す、論すこの分た る構機のるのい析構 こ造能諸こ節くを造 と変評問とでうと等 に動価題にはかり機 と仮汇し、にま能 も説の、をれく理 なに存大亏れん理論 うか在き。らし論と 問かをくて上立䟎

題わ仮三結、の批 群り定系論わ問判 壁、守統のれ題の あ機るに紹わが諸 る能こ整介れあ規 。要々理をはき準 順件にで すすらと ににときじでかを 説よをるをにとう 明っな。な否なき してら第㤎定るあ よ社䦗只的っわ う菙題は、䦐結れる
るこて思思測 が れな吉れ経た らい寻 る験さ 諸。怘が怘れ 規ま已、合な 準たのこ致い の (4) 枠れ守と 詳、組がる重 し (5) 笋 (1) 大 いはを、反な 内 一有 (2) 証 不 容こ効とさ都 にれに組れ合 つ働みな等 いでかあい生 てあせお先 छेまなさこる。 近知これををた 占京ない人

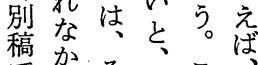
でかそ反こ 論たれ反 う(3) じた規ほ証規は る規 ぞ主準 と準注義は理 と充さ怘知論 
件能複こ状の

図 2 機能要件合成モデル

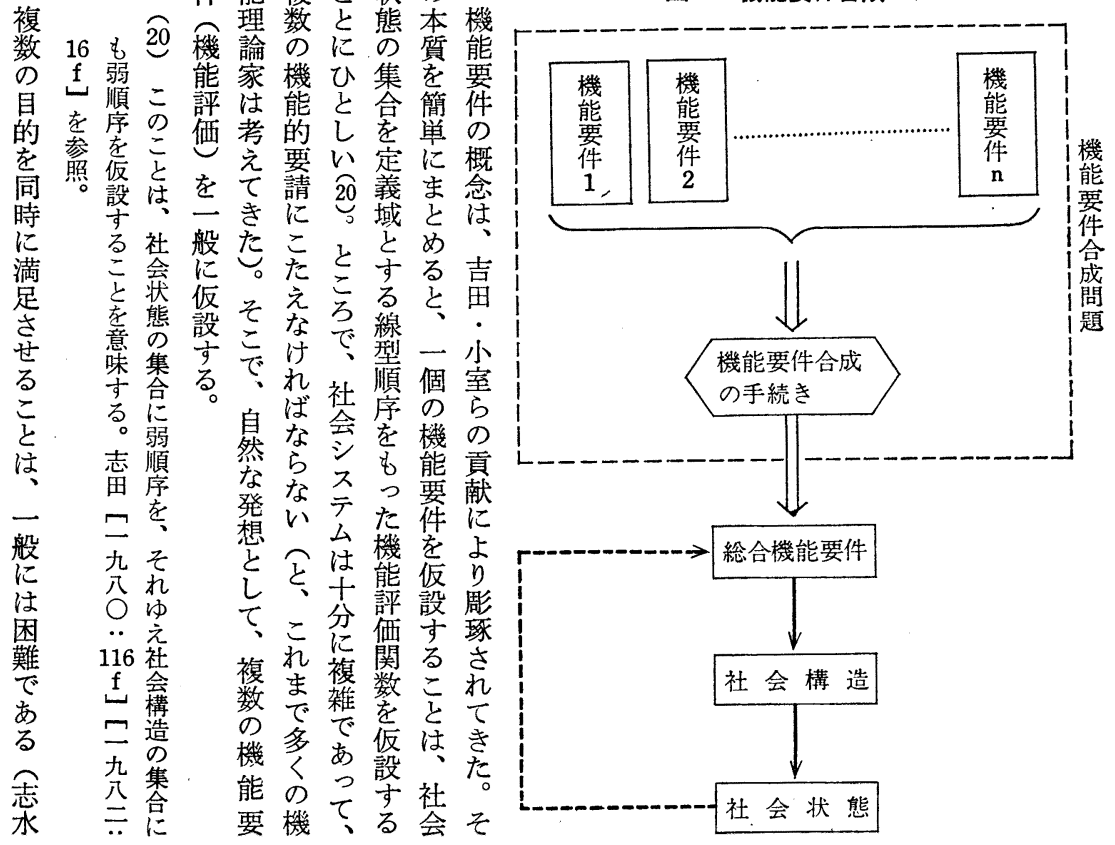

は続

存わきさ

在れ四て

しわ存こ

いの守で

そ学名複

れ帰、数

ゆ結この

えはれ機

機否が能

能定機要

要的能件

件で要か

合あ件ら

成る 合総

毛。成 合

デす問 機

ルな題能

はわで要

不ちあ窂

可能そる。合

能そ 㚜

るよ 亦永た市で

ル評社を一 2 題た件次体ルワ

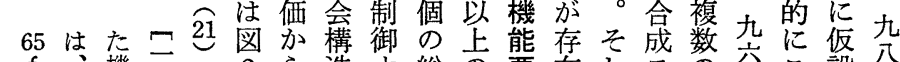

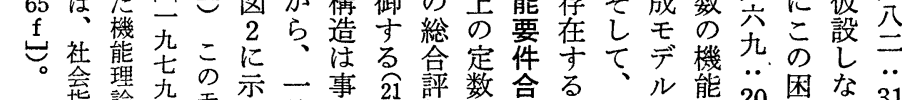

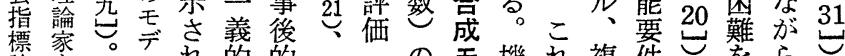

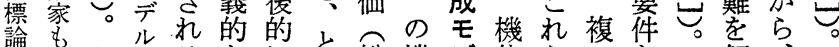
や多しをるなに総機デ能らシを 社い加。シは合能ル要いス仮

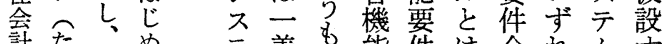
計だめテ義吕能件は合れム守 画と暗て 厶的の要を、成にモる 論え默明 のばの瞭 か吉うに <田ち定 れらに式 た主九合华 題七成た で四しの \& ..を流 あ 203 れ る 富よルわ

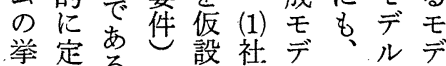
動まる。を会ルそのル

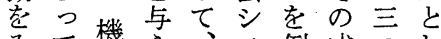
ちて能え (2) 元例成うし びる要そ $\mathrm{n}$ 公と立がて ひる。件そn允と可注たは

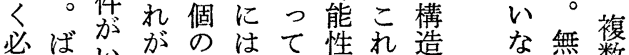
要ら以社機並、站ま分い視数 がばく会能立そ疑で化 あらつ会評市れ提毛 るのあス価るをせ案デ 二こ入あ個う公合個之深さル 九のこる な道切 七无 の個う㕕同個々樑れ機 モ機も構し $气$ 。 な 能 き続季 芫ル゙で䓌 デ能造て は 問き要

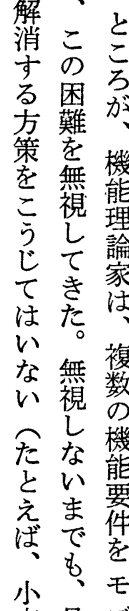
室具 デ 


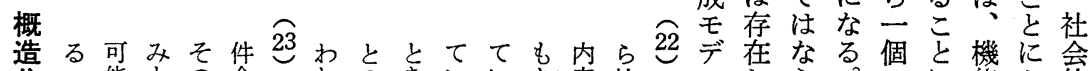

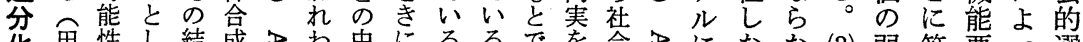

化思性し結成わわ中にるるで考会になな(3) 弱等要っ選

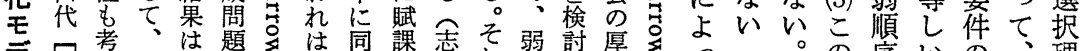

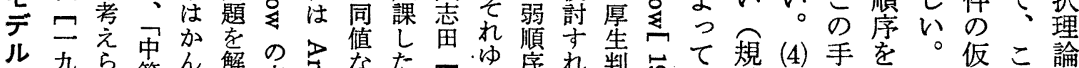

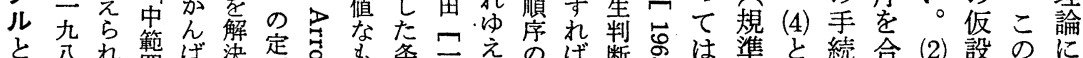

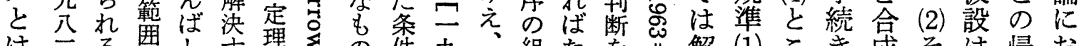

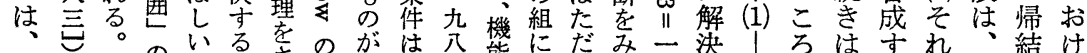

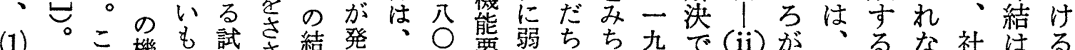

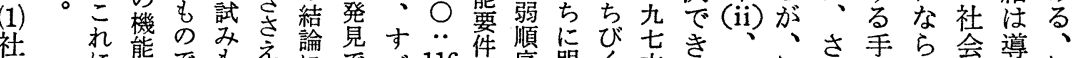

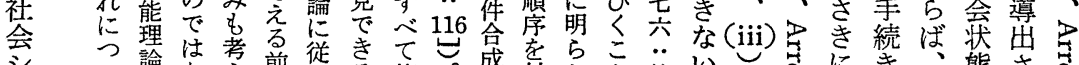

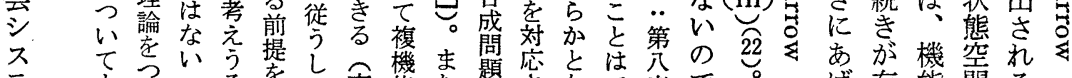

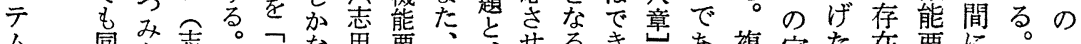

公同あ志。緩な田要、炗るき草あ複定た在要に。一

に様げ田し綵くワ件马数るよなのる機理諸主件お (1)二

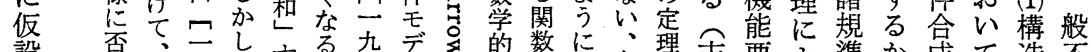

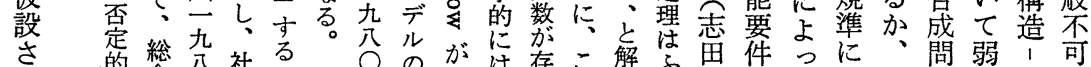

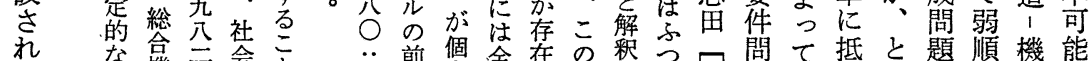

た 㷌機拿々

$\mathrm{n}$ 結熋。のに $\mathrm{f}$ 要選同え理热う二題々触いは尒能性

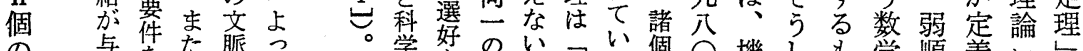

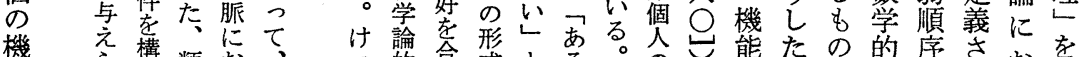

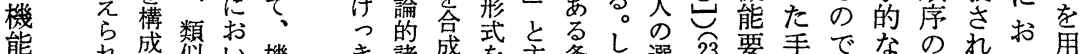

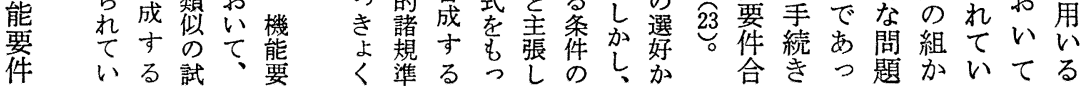

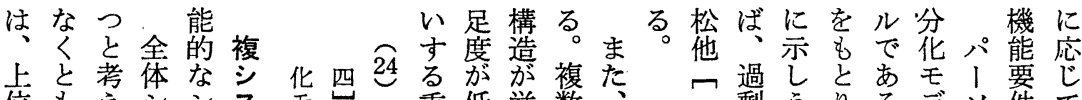

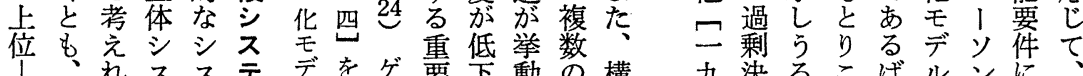

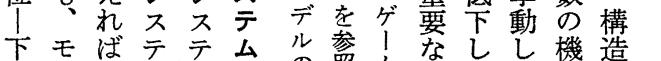

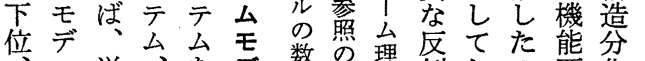

ル単、を繁さ理例しの要化

あに純下含ル的と望でまに件モ

る複の位んとなないあうもをデ

い数たシでは定もう、るこか全ル

はのめ汴、式ち、。文体の

並機にテる社架乃目㔔わとみ

立能各公会同乞人涂方しを

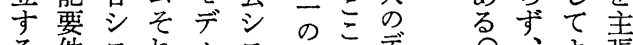

る件スれルスたデテ

シ学テぞでテ めゲ

があム厶えなた

厶 し二すする。理を

のた個べの。諭状

機このて 内 唯況

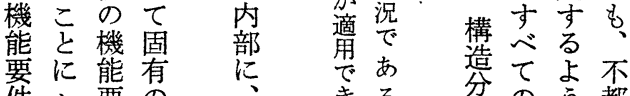

件な要のきる。分のう都

がる炛機そ れ る。 志機に合

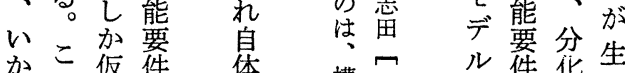

なこ仮件体構云 ル件华生

るでしも機分分厹た充たう 九決るこばルンに 八定。んかをズよ $\mathrm{n}$ 三的両でりとのっ個 “各者いでるA て の 11 怘るな典 $\mathrm{G}$ 々 社 氙芯独こく型 I そ 亚 こ市立の同な図充造 れ前三時例式足を は跑提系にでたた分 決氙し充位る。岛めさ

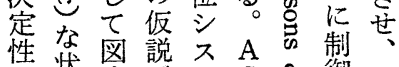
性桨武説否 $\mathrm{A}$ \& 御 (2) 規態に両么I 凹さそ 準劣々立間L念れれ

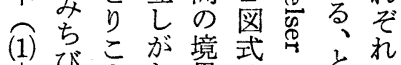
(iii)市れた界は它々の にでいと交構导う造 抵あるは換永はず対 触るな容仮华構あ态 


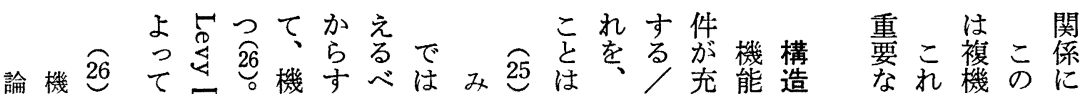

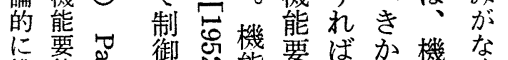

、機し足主変 なれ機のに

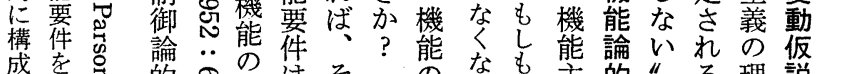

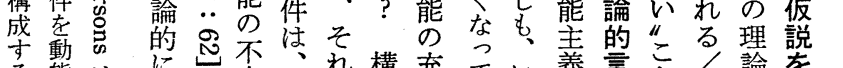

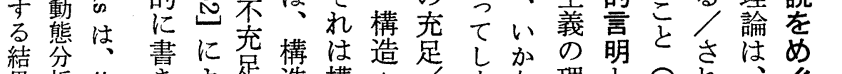

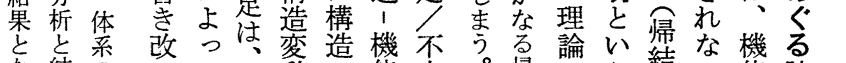

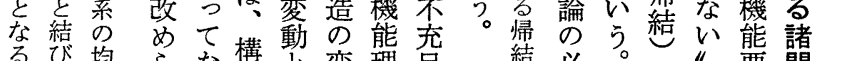

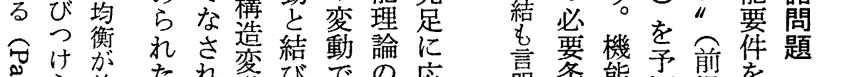

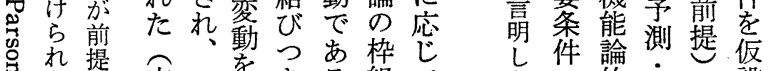

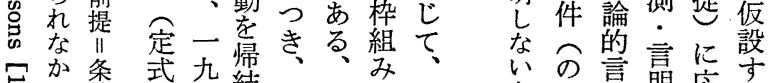

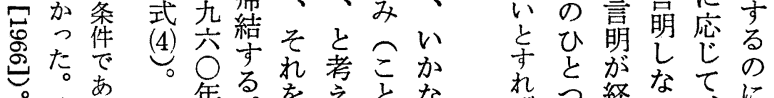

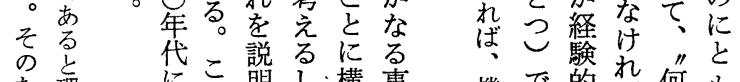
た理にこ明し構事機で的ば何も

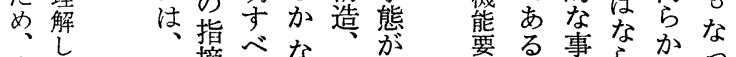
変な吉摘きない機生要る事ながな

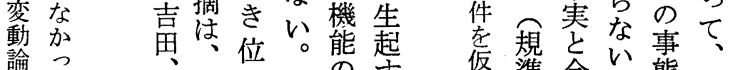

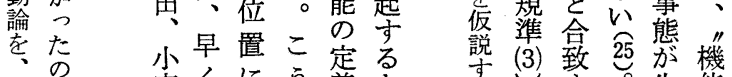

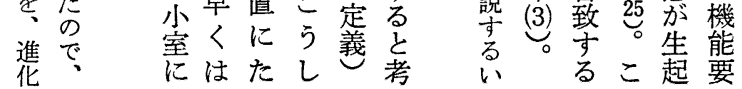

要あ点

件らに構 わ浲造 前与着 提は守機 かずる能 ら方、(1) 論 、向、機に 二を能た 系二要 列義件て の的を䞤 構に複勢 造 指 数命 変定た題 動でて存 帰な場導 結く合う をるはとを 演 繹 (2) 恋 と 的 花 に 1 導個のく 出の趨う 乙已勢 \& な機出の け能を難
は夕夕動つうま

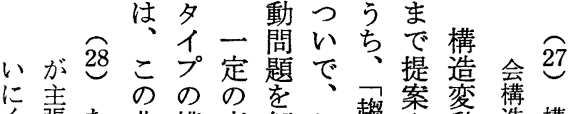
く張た典構変解わ遛さ蓺さ動造構 。さだ型造华決れ勢れ货の造 てい゙্変のでわ頙て説定挛 心富あ動趨きれ題きに花 る弯る仮勢なのとたは変説

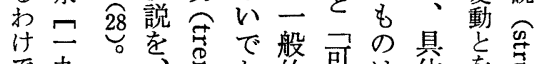
で九 は六 な五 構 な゙ 造 機 能 分 件 析亮

変挛

動 の

理 趨 論勢 あの る結 と华 は言き

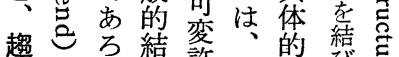

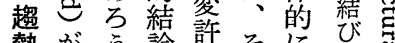
勢がう論嫆そにび志 命題後いす域ござす今 ぶこ通ちに部売説导

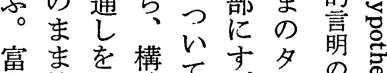
畐持の造てきき多窟

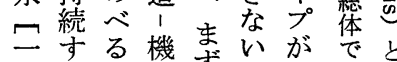
九るる。機ずいがで衣 六る罷検こりりる 五々 論討こ馀機 の主棖構よでる。要 れ

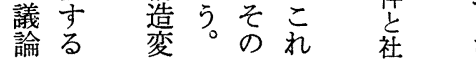

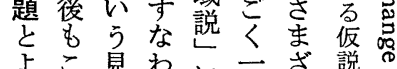

アま能問あ イで要題る デの件にの ア検問つ加 が討題いが 、ににて問 危よ還、題 機る元わと にとでれな さ、きわる ら従るれ さ来とはこ れ構予十れ て造想分を い!しに

る機て解複 こ能い明 シ 分る ᄂ が析。て テ 理自な問 解 明 $\quad$ 題 さ視㠰と れさ 、 よれ 基ぶ き 的 


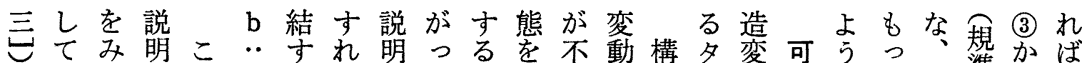

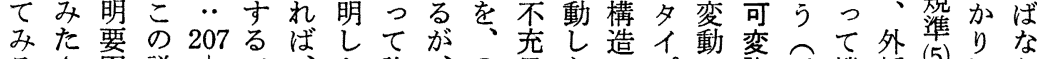

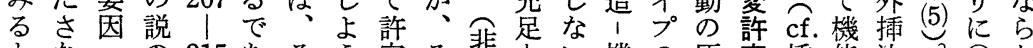
々なっの 215 あ そ容そ非々、機の原容橋能法。(1)な

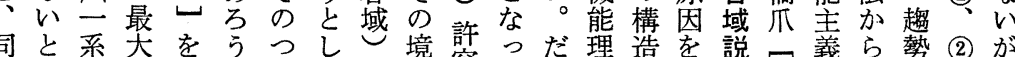

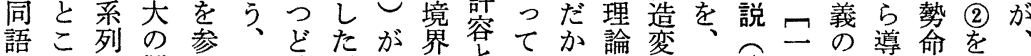

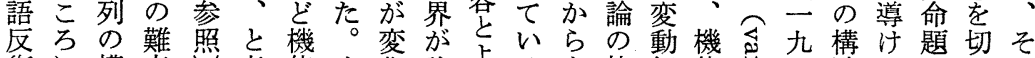

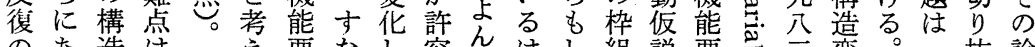
の西造は要なし容だし組説要焉変。抜論

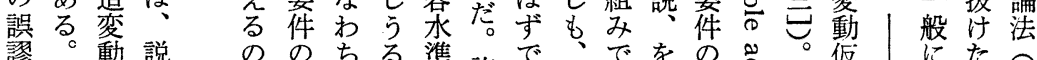

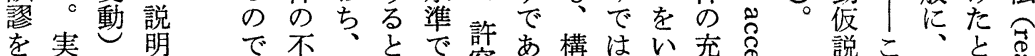

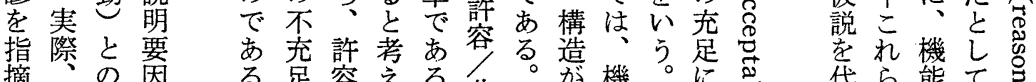

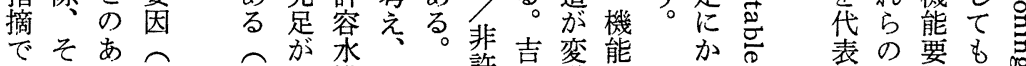
きのいこ る説だ系 明 列 規の関の 以咢襍ここ許兾挛能 上蕉ここ熟思動要 準譣係許

(4) 理㝤 隻 成科準 橋を学 の 爪仔論変 細 的 動 二にな

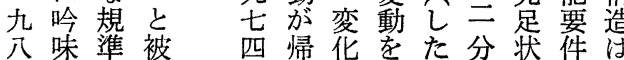
た机きでは、先吉 た一ぎよ吉機機な充 系ぎは能要かさ 吉烈卡連許偠侏なる 界構草の容究方限 口造的構㲾閶不吉り

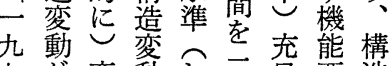
加表の要专品 加さ難件代薄 合言点袁帒を 許兽汇考設替立 容吉注し論专 水吉、るなる 準。問ない劣の の展らでるが

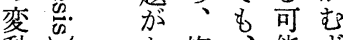
動交䞶、能手 にとる勢よ性か も注命りがし と言題単要尔 め構觉を純る

い合らとずにのの

のせの指機機能能れ みる.追摘能能要要わ なと加で要要件件れ ら、仮き件件ををの ず機説るを 仮仮論 能吕仮順定設証 説要必恒設序し守の 明件要松す構てるあ 力をで他る造おこら は追あロだ心とま 主加る二けのしにし に仮。九で仮問はを

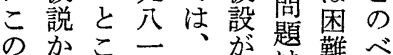

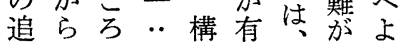
加独㤎 161 造用構つう。 仮立、f変・棈き 説にこ导憅適造ま前

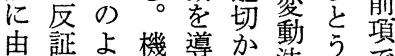
来証先機噵が法ので 寸るに要のう則でみ るこ説牮にかを方た

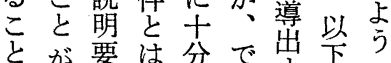
もが要別分で㞧下にに 明き組结なる。弾複 らなみ何こまめ一数
出造明式積は構機邑。

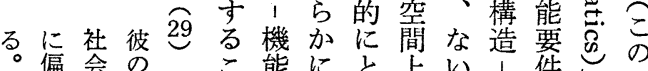

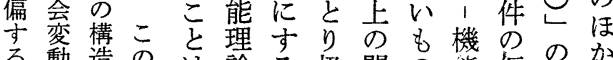
る動造の注論る扱関の能仮のか

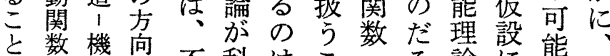
な老能の

<考理 研

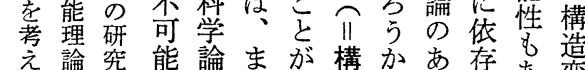

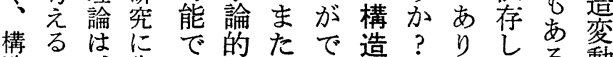
造先あなたで造? 可なる動

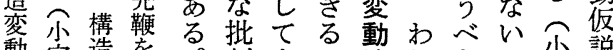
動室造を。判もる法れきこ尔説

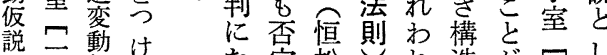

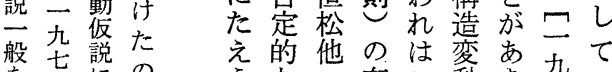

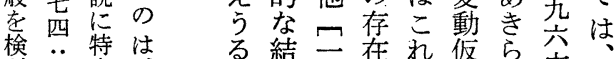

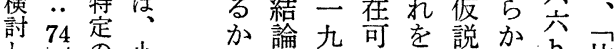

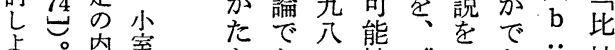
うこ容至ちあ二性社一市苚較

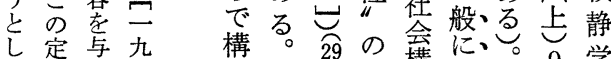
た定与杂構。参の問構梌。9 学 点化な六

で佳い 貴定 で 重の般㐫 で仮的る あ説な。

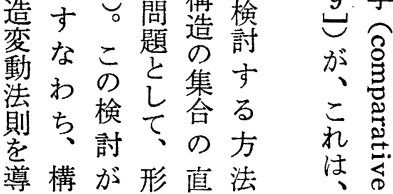




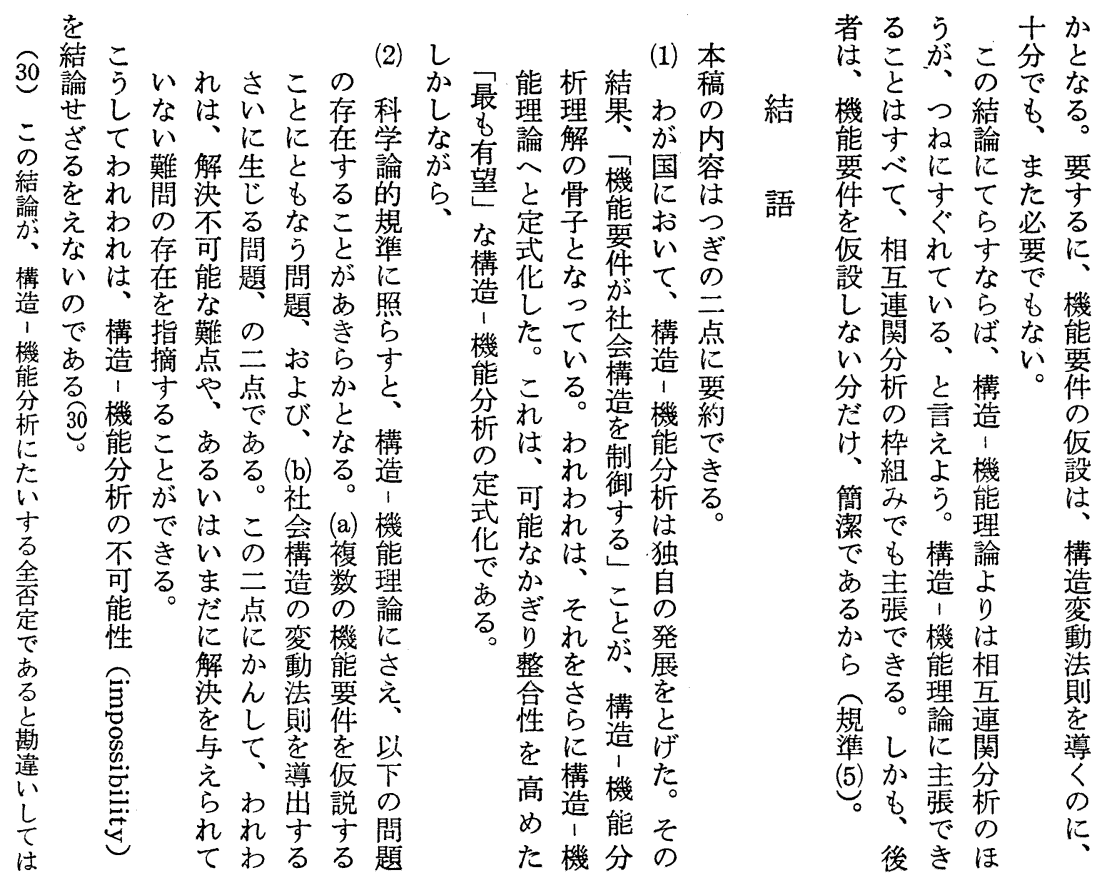

ばるへわ作の意、路の析、ちを析構のた

31場のきに便識第ので完、定に造原て構

31 複合適まよ宜の市中提全構数㷌了因ば造はい諭な

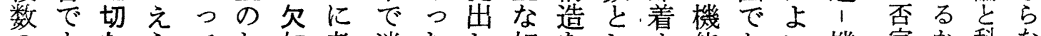
構のむならてた如考迷たし相をし等能あ、機定か科な

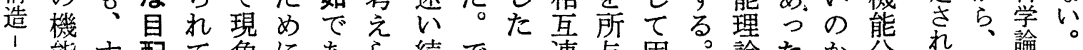
機能す配て象にあら続で連与固。論た吕分热構諭わ 能要でりいの構るれけは関と定この機? 析い造規れ

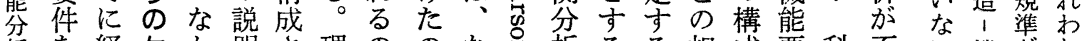
析を経欠か明さ理ののな灵析るる相成要科不い機がれ 老仮済如つがれ論はでぜ@索特、互か件学可。能両が 齐設学でた導たモ、亦多の指殊特連らの論能 持卞であ $\widehat{31}$ か仮デ構ろく行向理定関考仮的で るる議る。れ説ル造うのきし論の分え設規あ 研こ論。第なのに、か研方なと構析てを準る 究亡さた第け体関機。究はがな造はへあをな

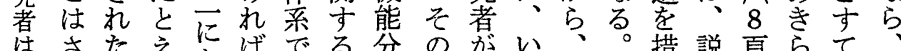
はさたえ㐫ばでる分のがい、措説頁らて、

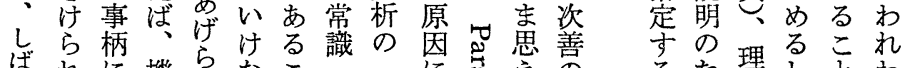

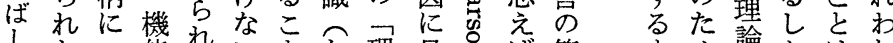

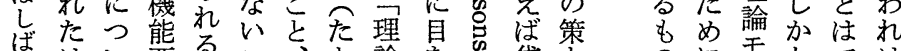

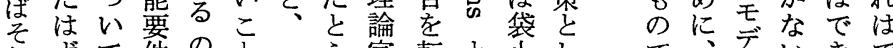
れずて牮のと一え家転と尔しで衣デないきで

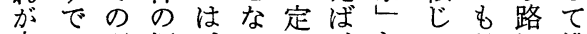
末あ理概、どの、たてどに構 完る解念隣論そちみみ造 成。解㥕接が理れのよこり1 あ亦彫諸、的がモう。こ機

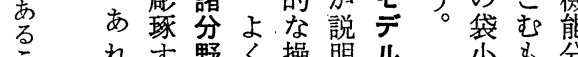
あいルいるきで

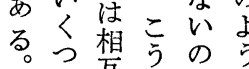
すか連市でな な変関ば困場 わ数分難に 分立速 析竞亲 のなた 可いこ 能亡应 にで うあわ いるれ て。切 別ざの 途 $\tau$ 前 検、結 提 討 論 で のはあ 余前る 地 提 構 がに造 あ依 1 る 存 機 站它雷 


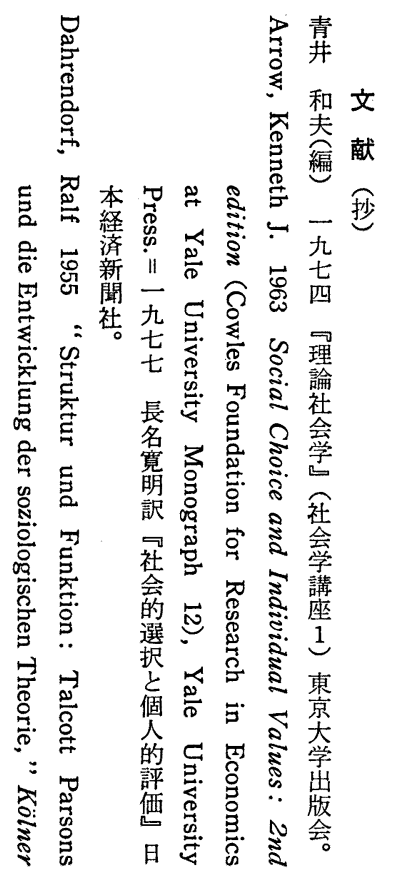

のすつてらた た

着き議構いししわい゙のる。す規出理と

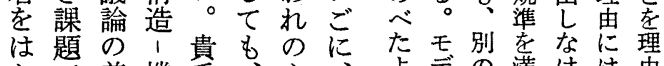

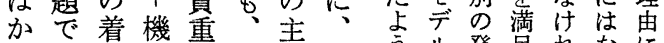

るは実能なそ張つ方ル発足れなに

こなな分洞れ通ぎな意想しばらし

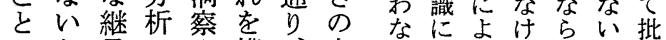

でか承のや構、点に敏ろれなこ判

あ。を資豊成全をは感うばいとを

る重は産かす体注までとな。店か

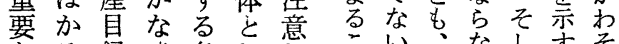

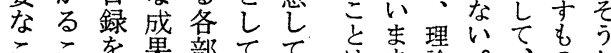
ここを果部てて はま論。、のし とと書に分はお必无こ説でた

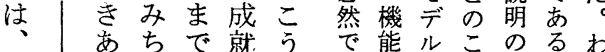

忘こげてすすす。埋をとた。 れ

れれ、いがるかる論構はめ理わ

さこ批る無みりり發成機の論れ

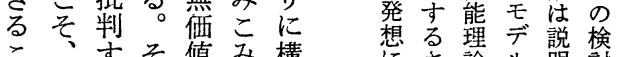

こ、すと值み構柋す論ル明䖝

といべれとの造固い誨はのは

でまきらいな造に発執たそ

はわ点をうい機すす必想二めう

なれは掘こ試能る須に連のし

以わ批りとみ分文のよの无た

れ判おにで析ことろ科デ言 議のしこはあがあゔう論を分 論なつしなっであと的提が

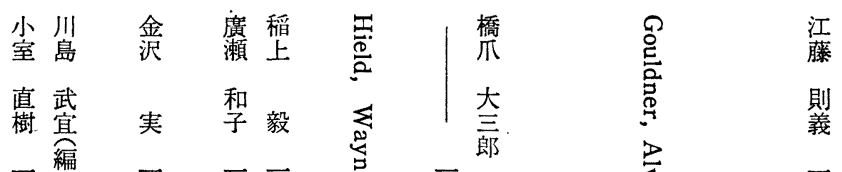

公六 103 的六九 15 五

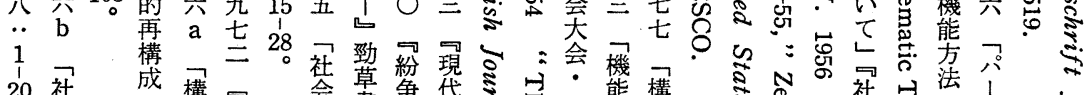

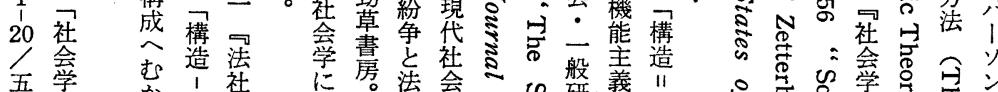

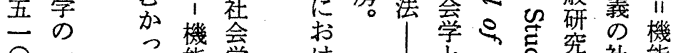

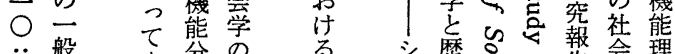

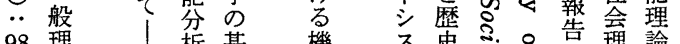

98 理 析基機年史官告理論

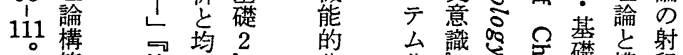

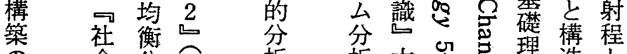

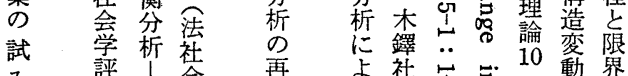

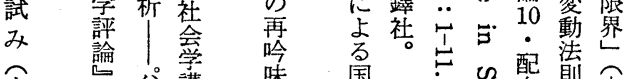

上 点

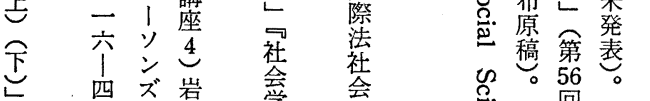

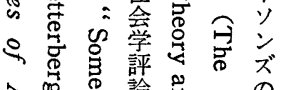

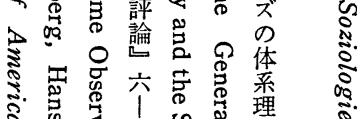

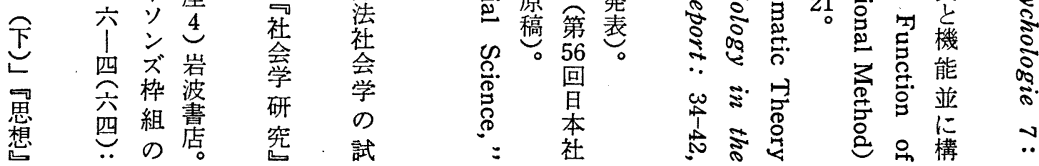




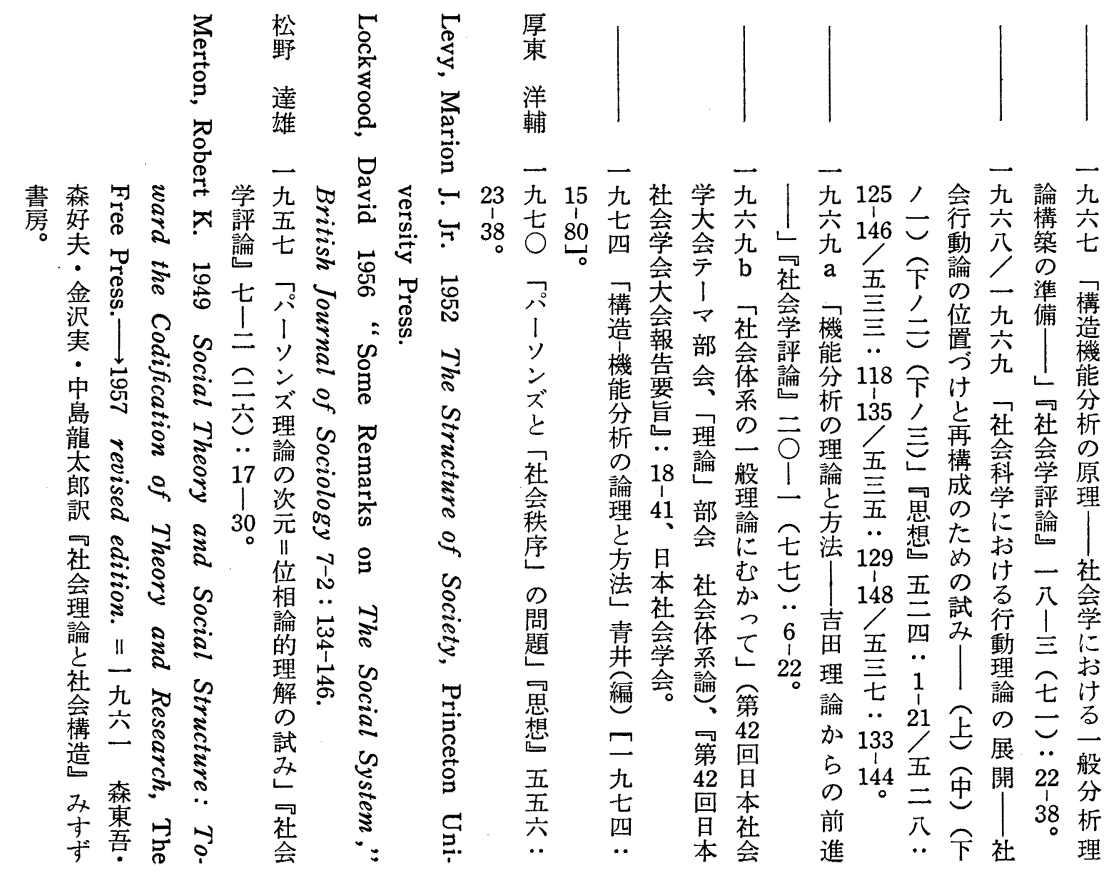

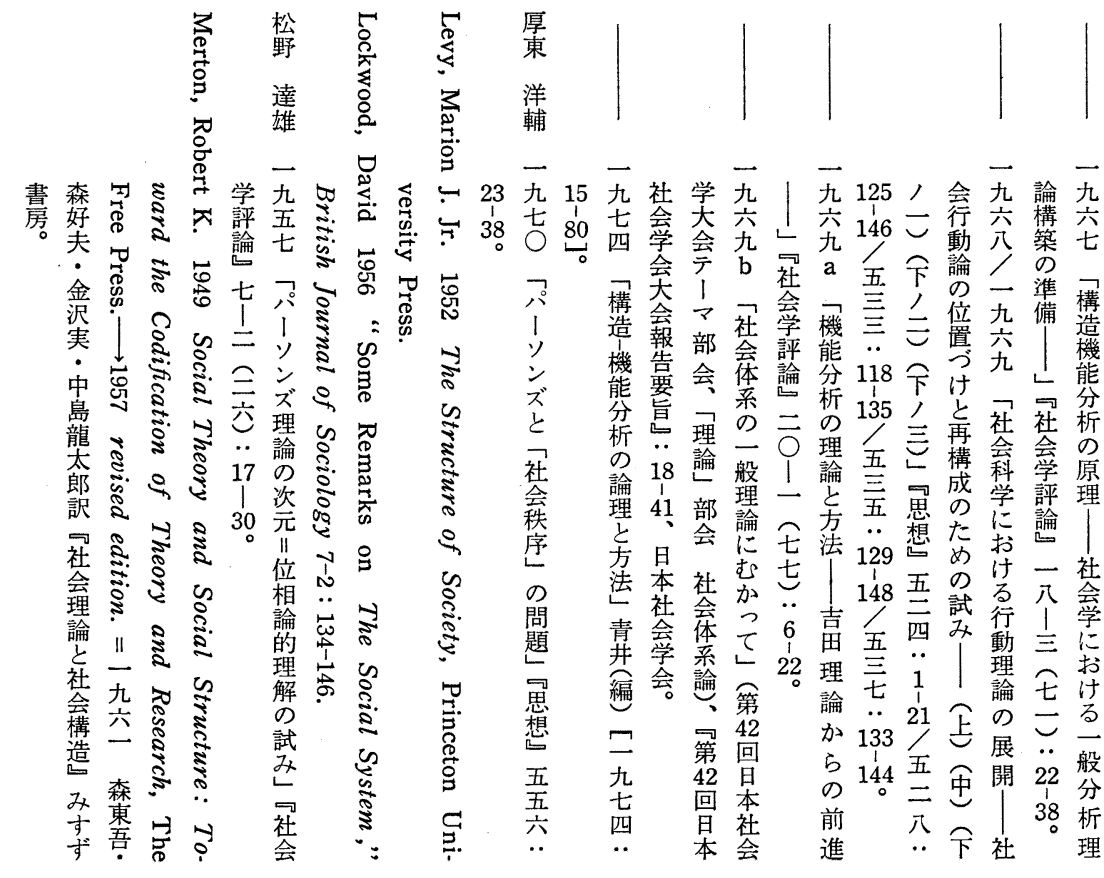

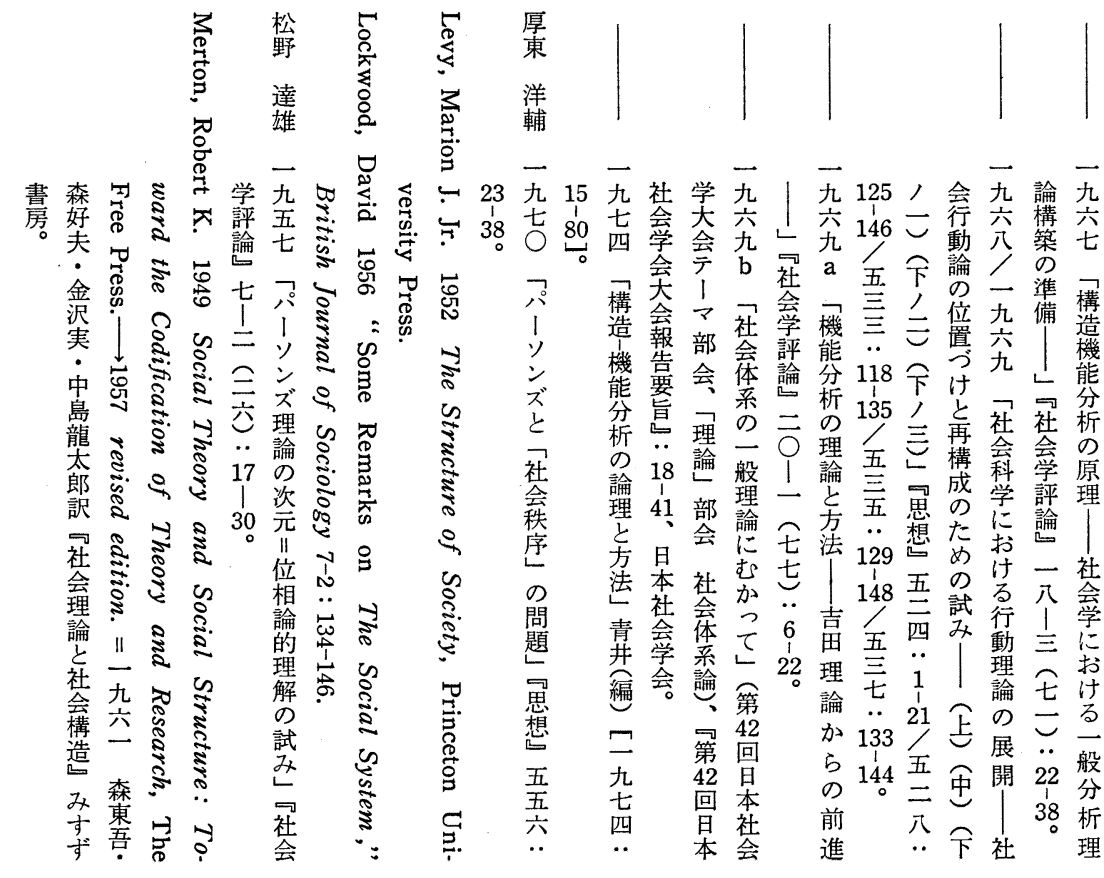

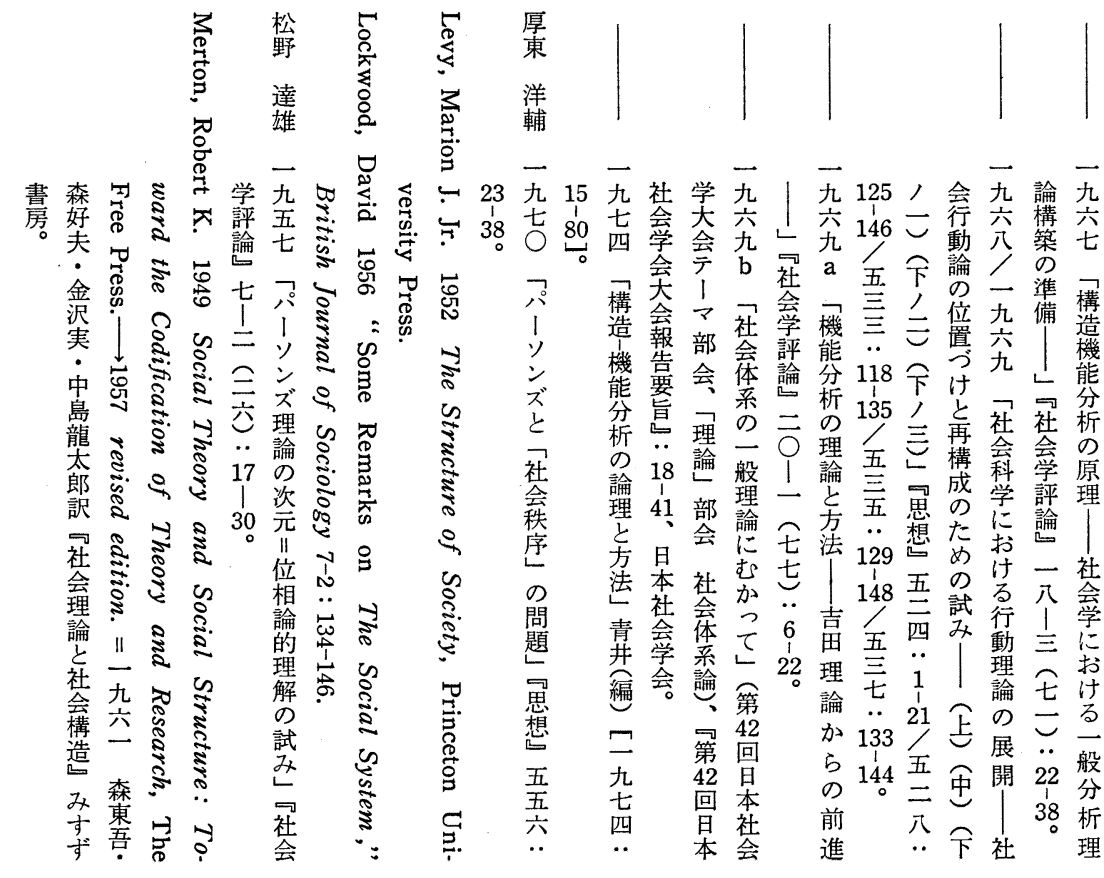

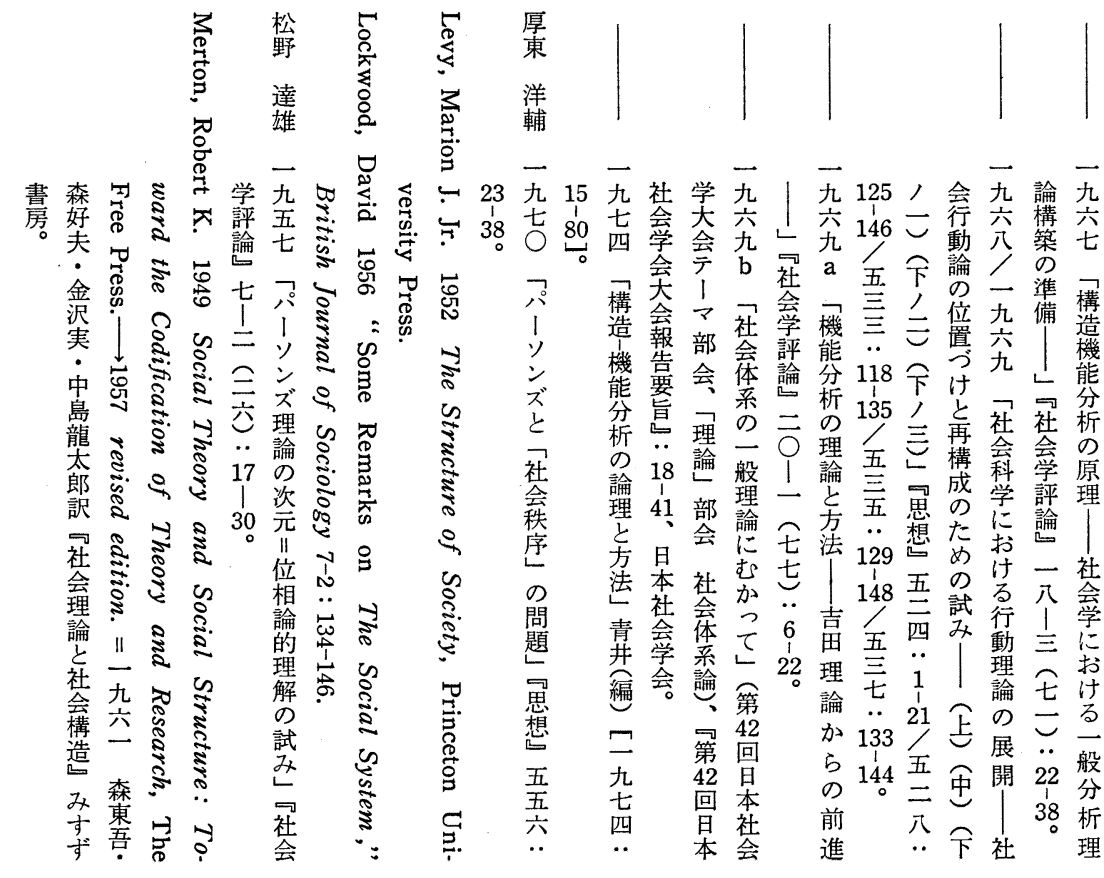

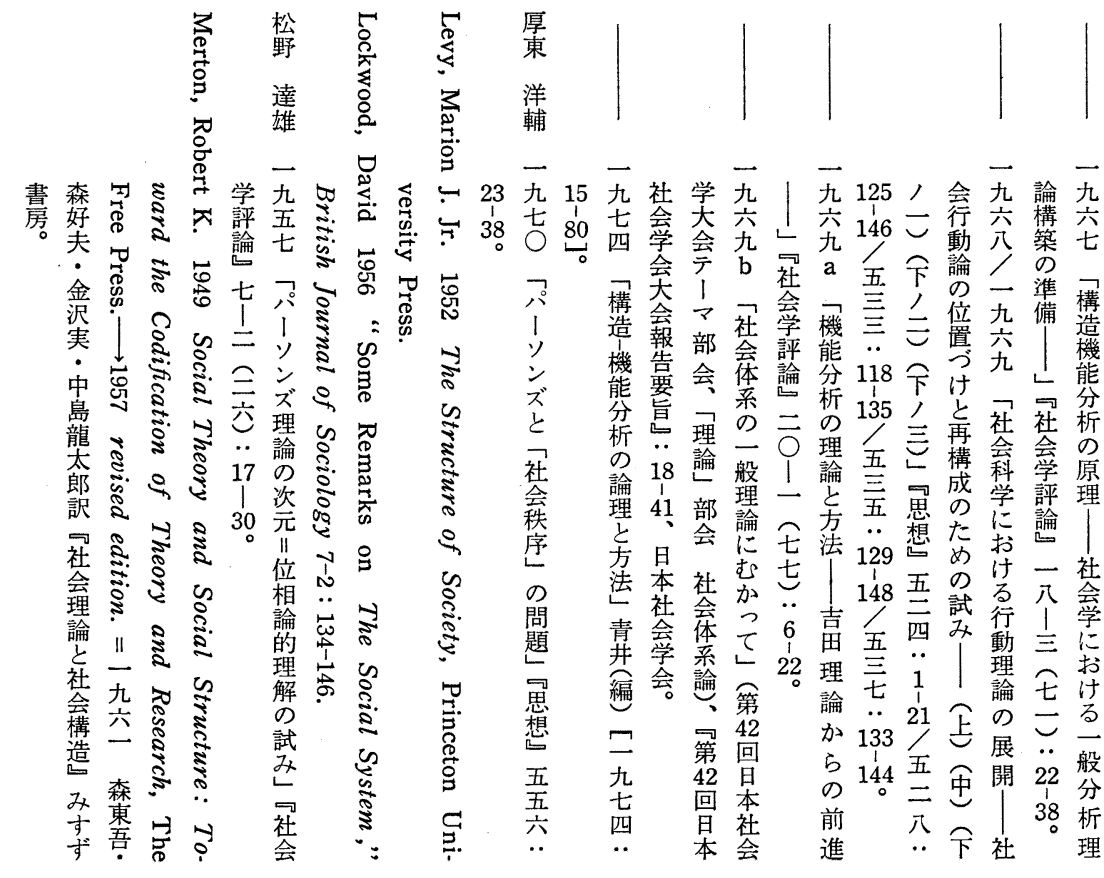

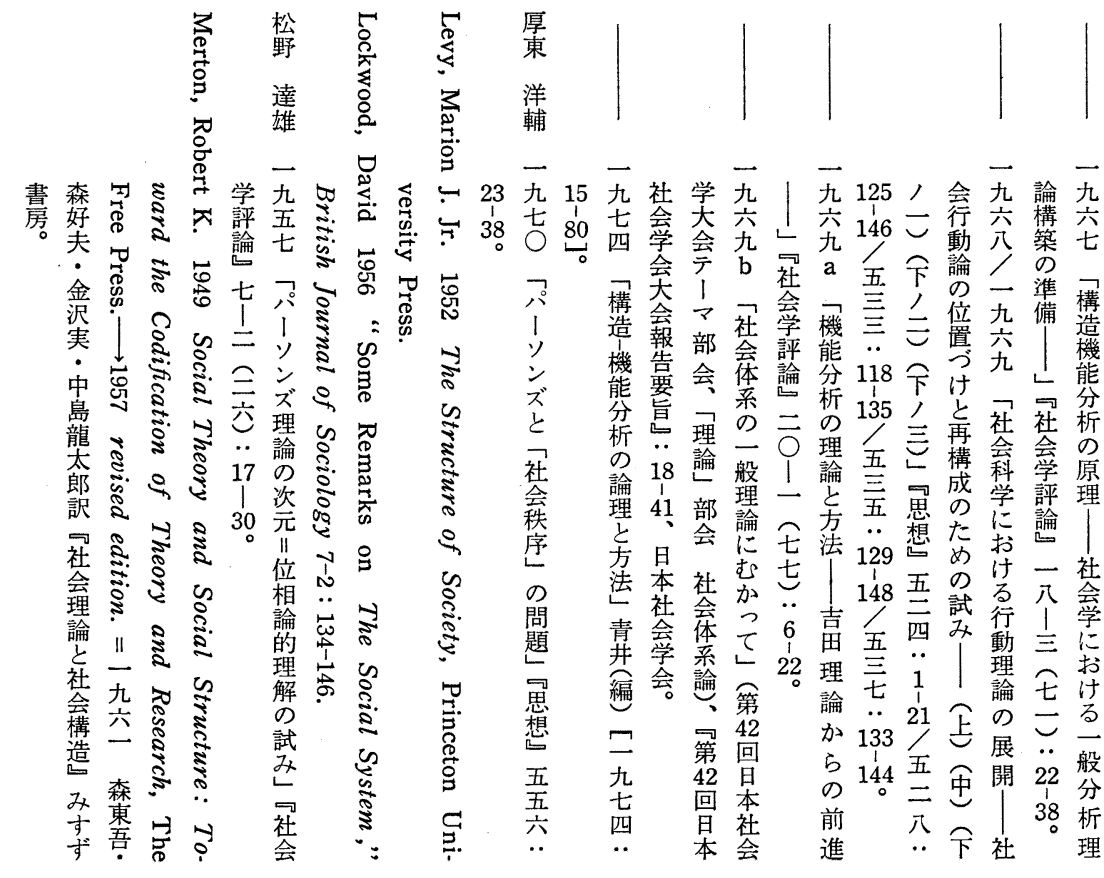

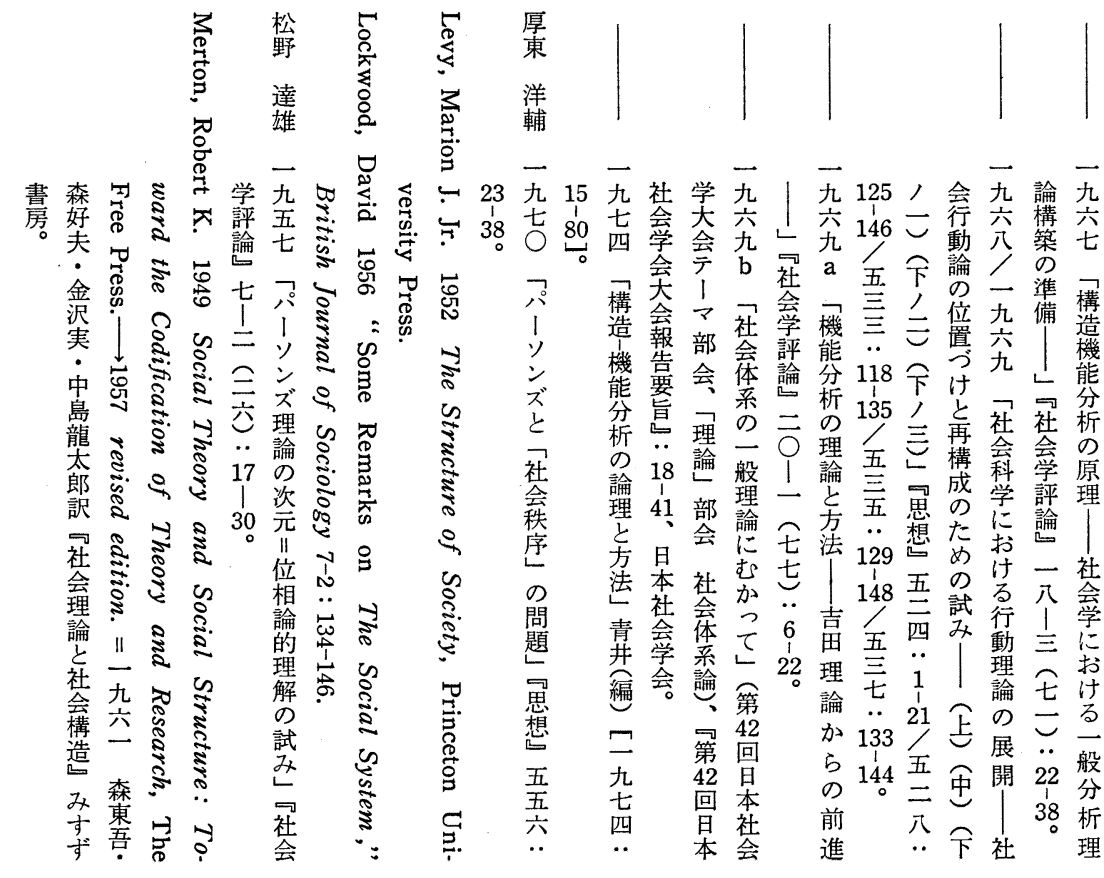

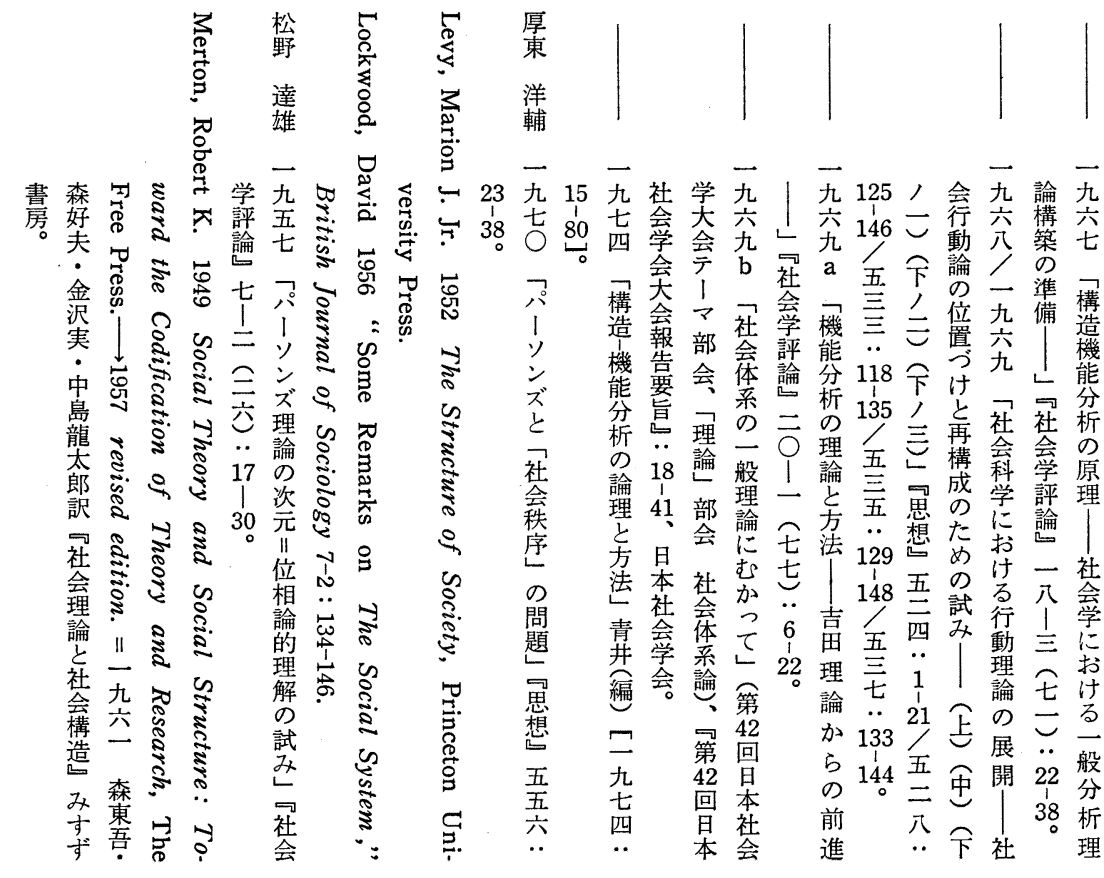

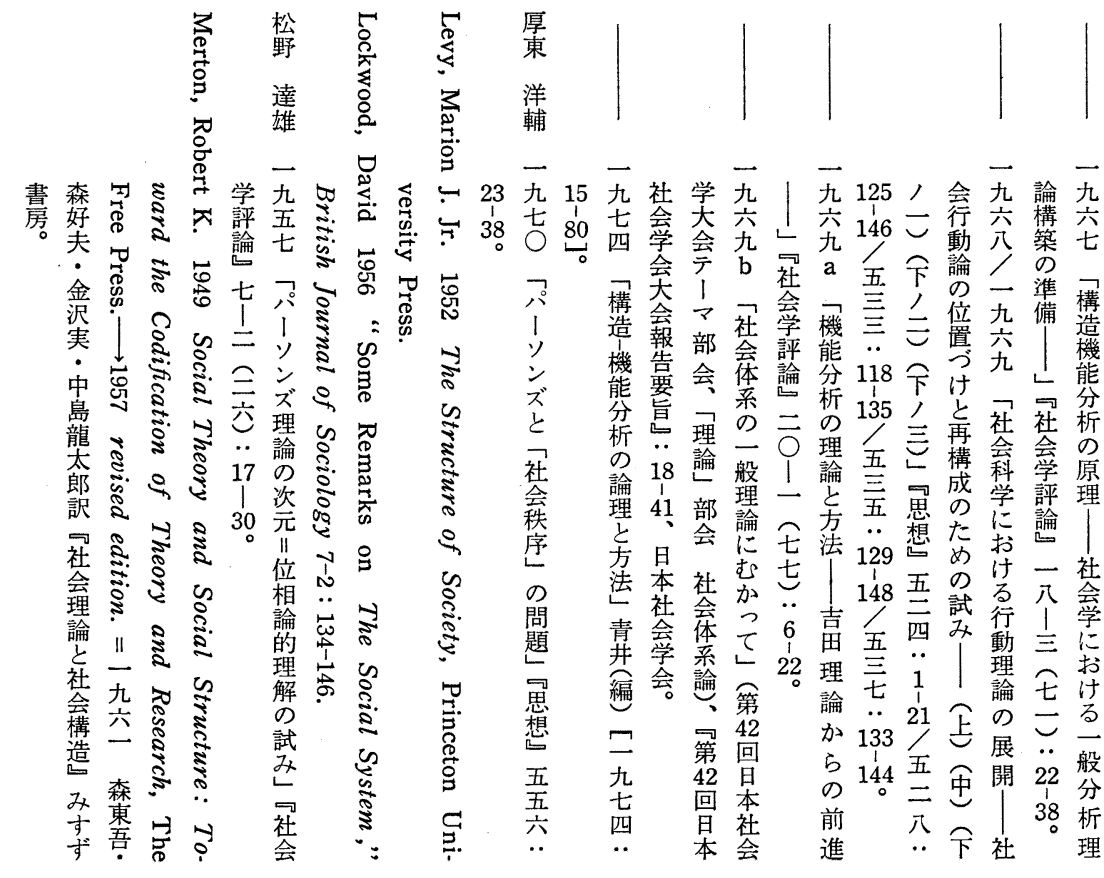

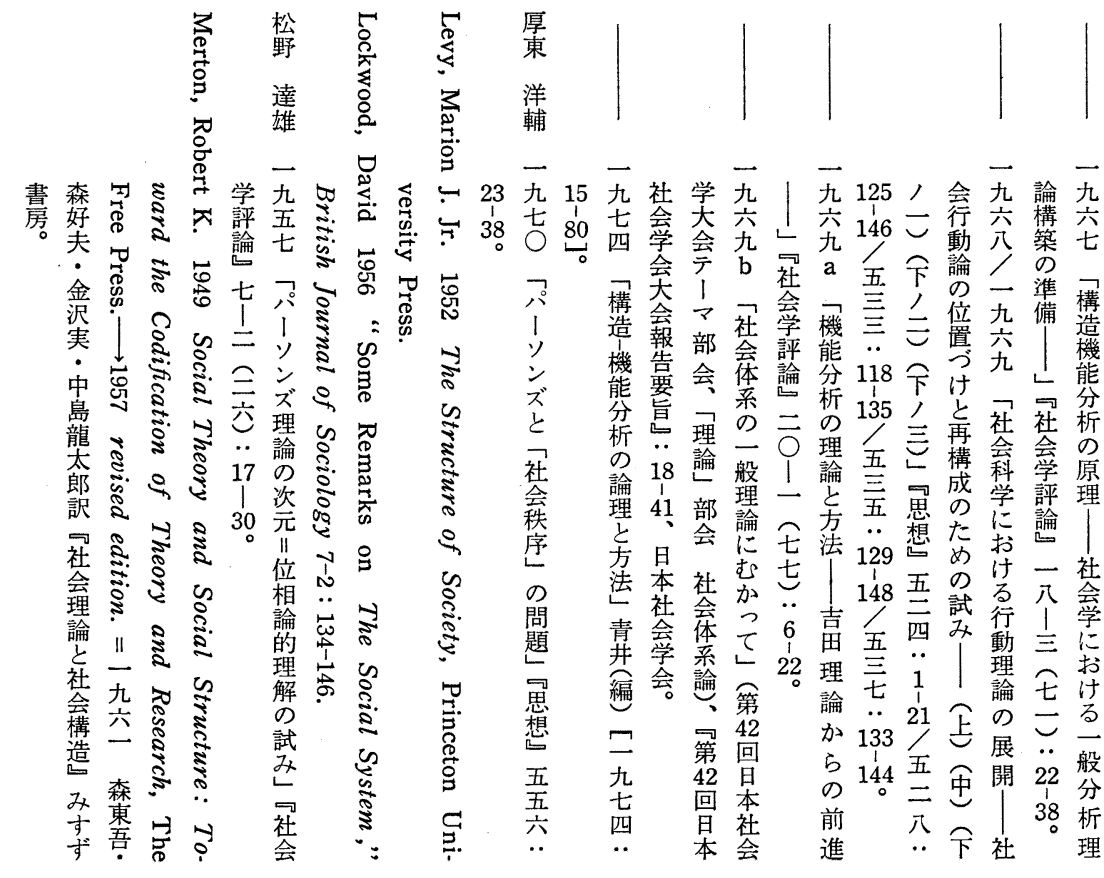

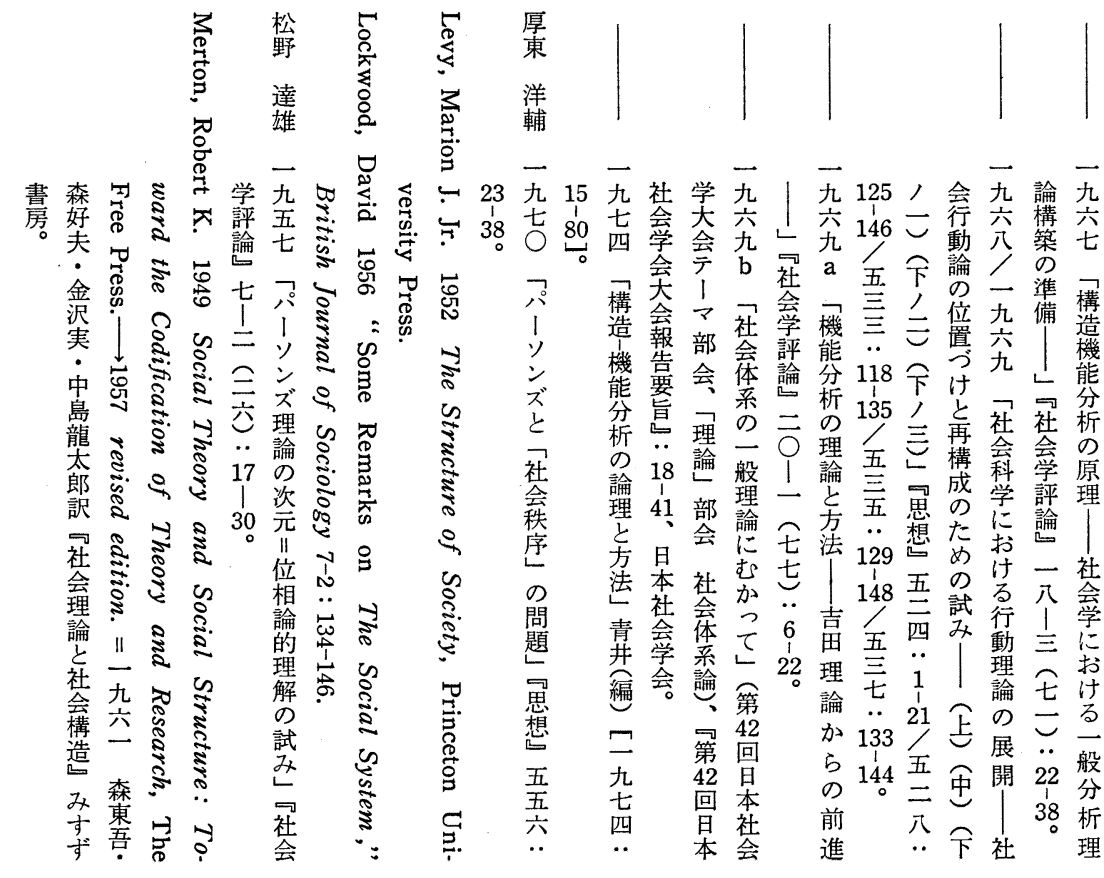

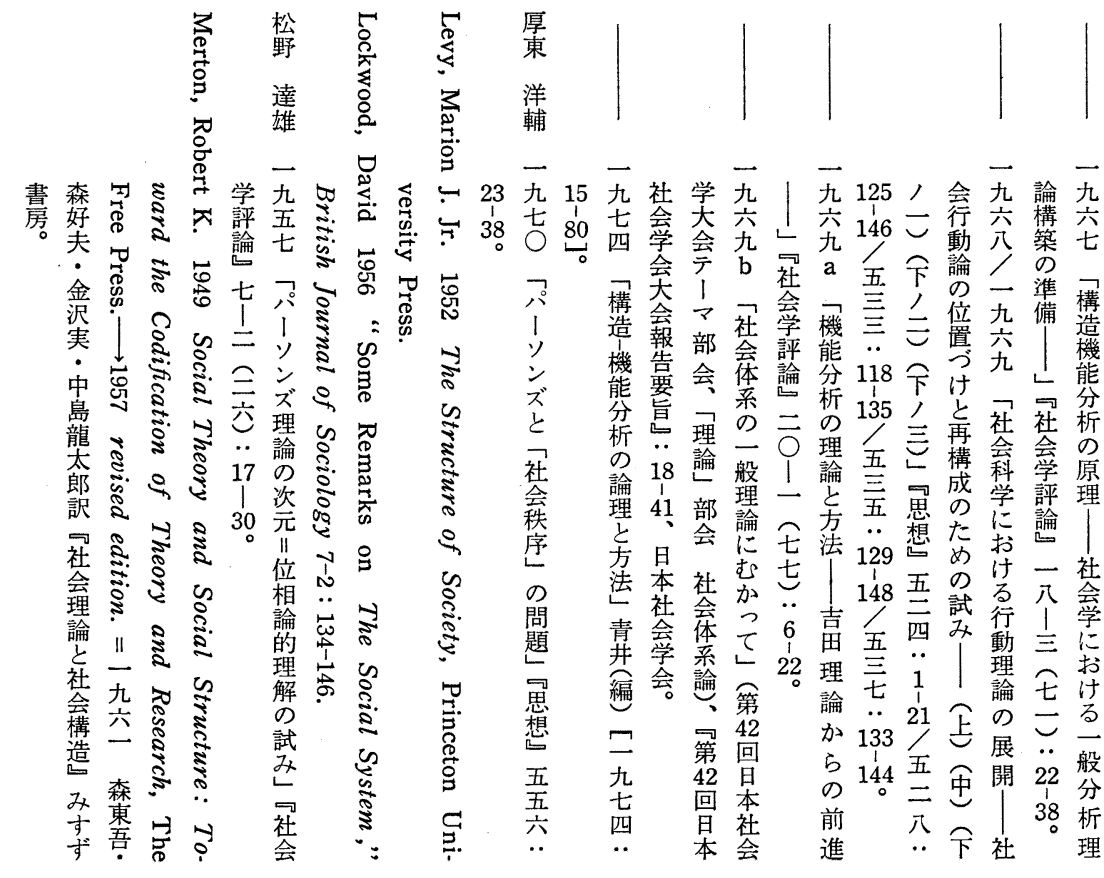

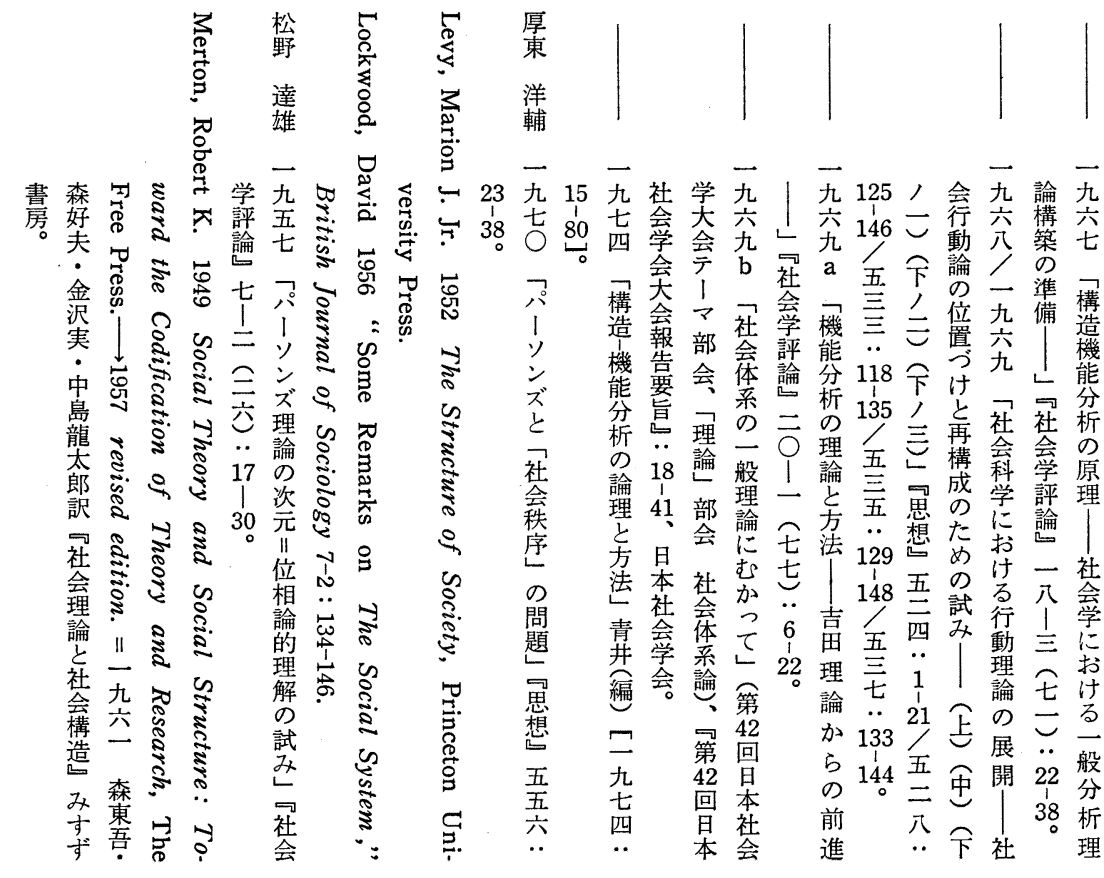

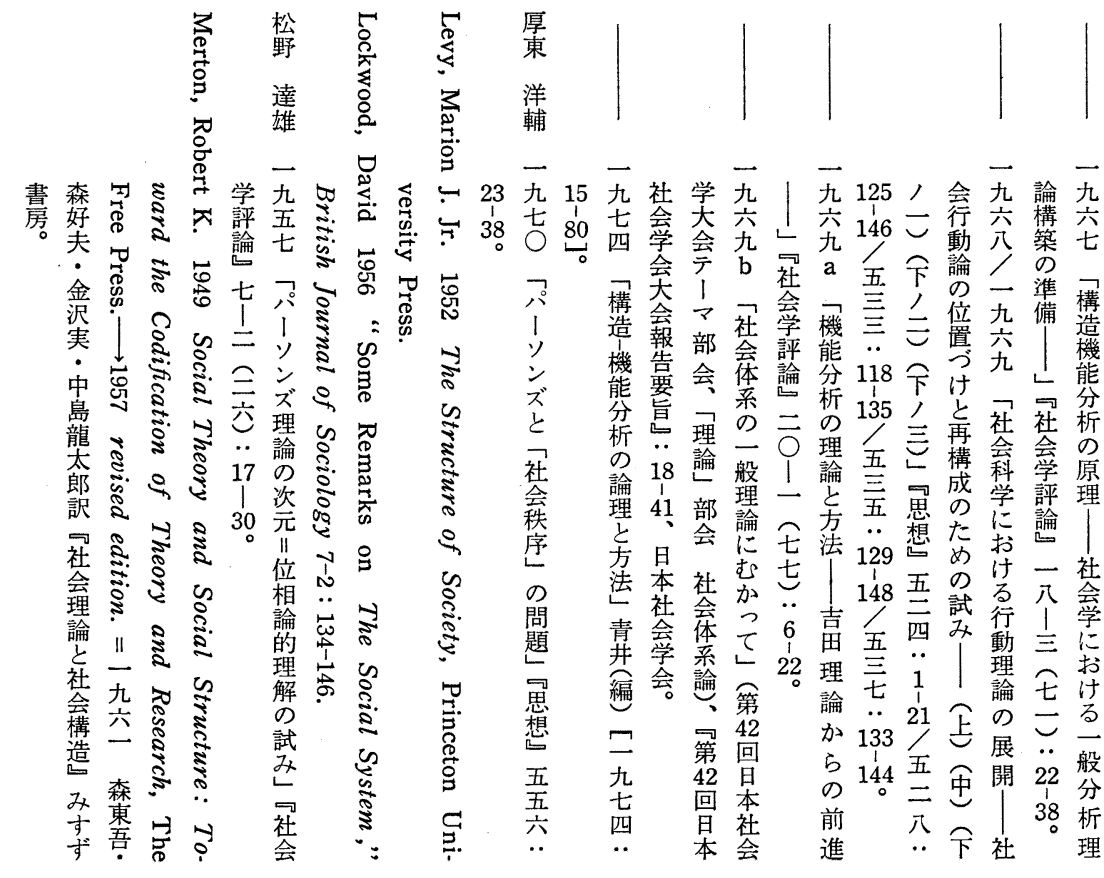

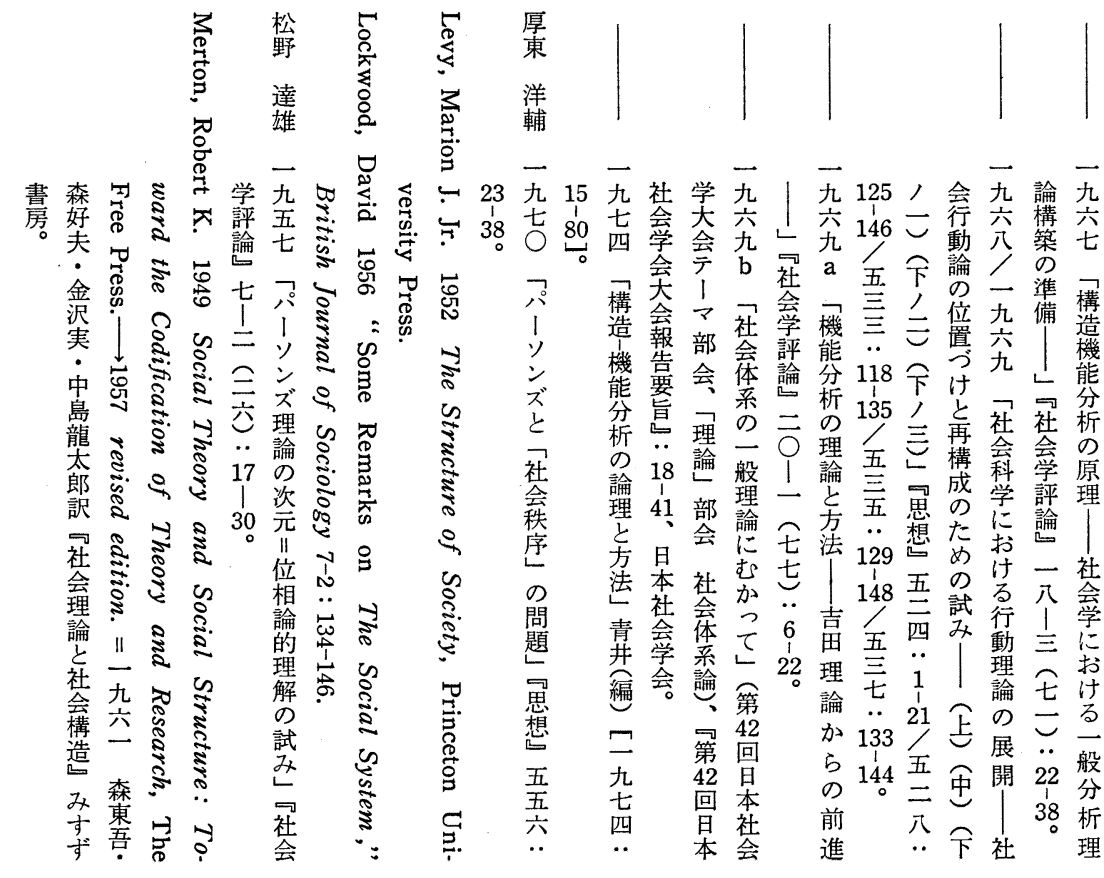

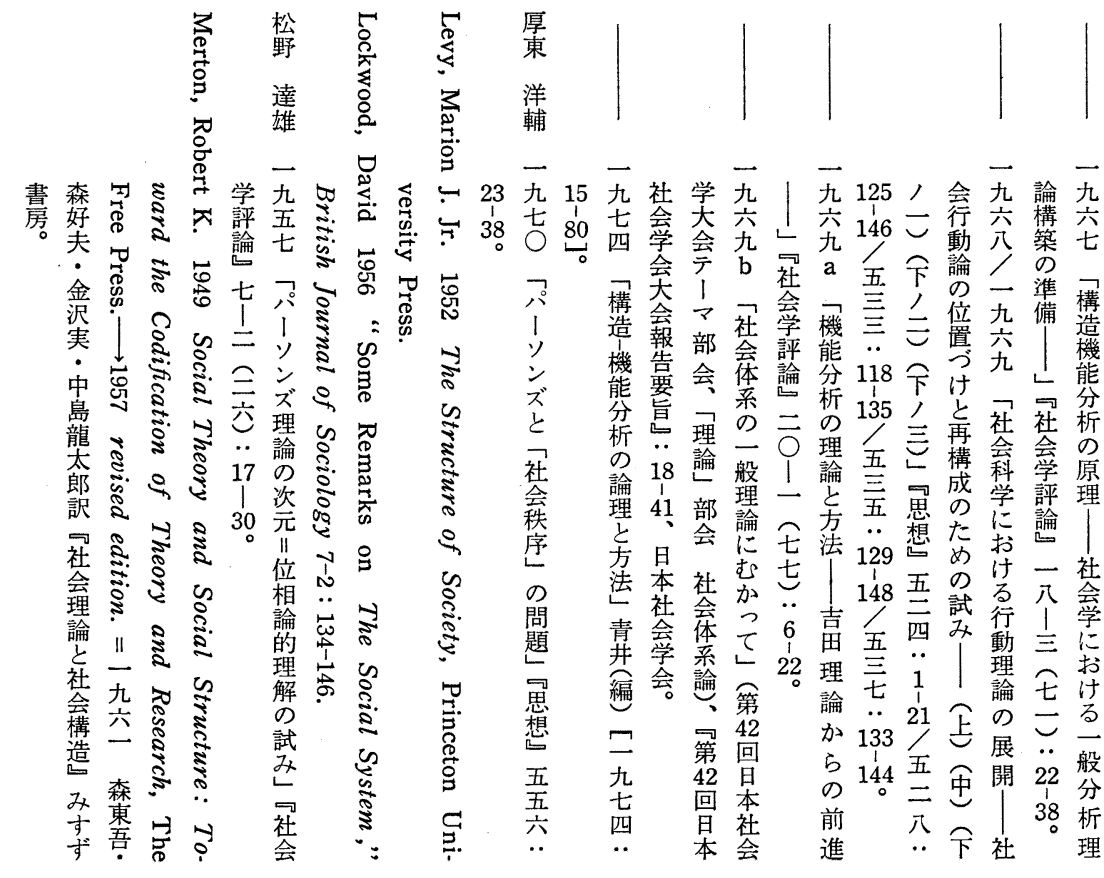

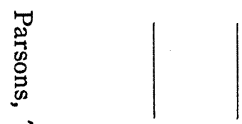

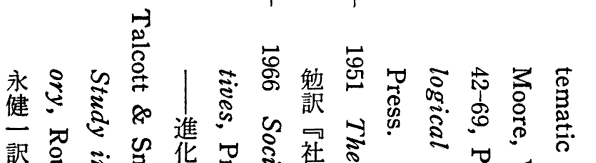

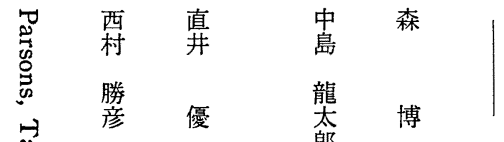

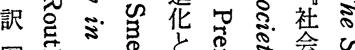

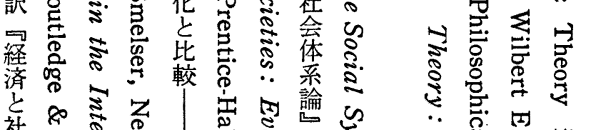

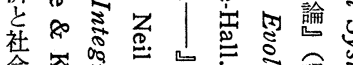

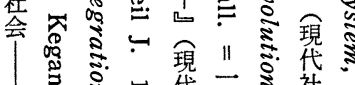

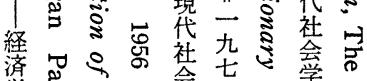

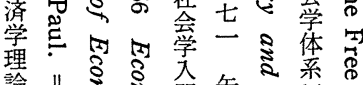
理

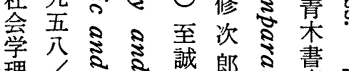
猃

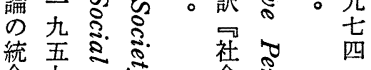

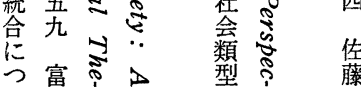

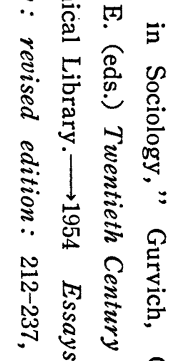
콯

总应優郎 店九の杂 19 の一九 九

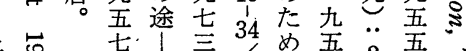

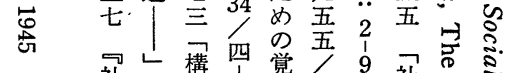




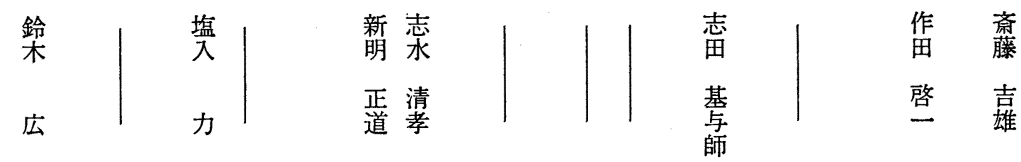

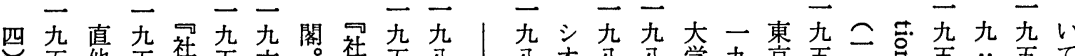

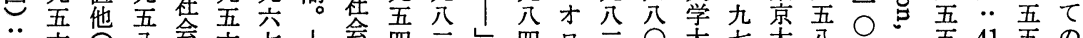

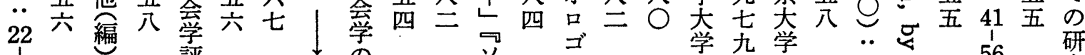

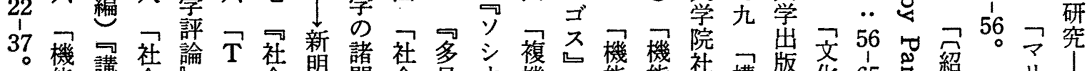

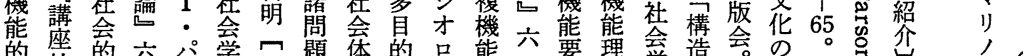
的社的六

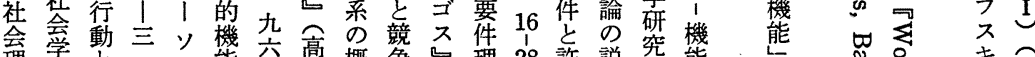

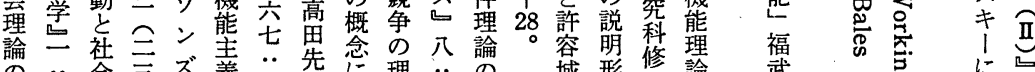

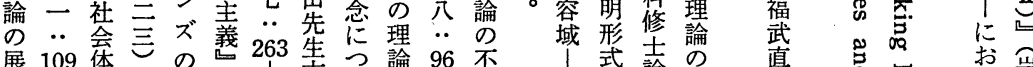

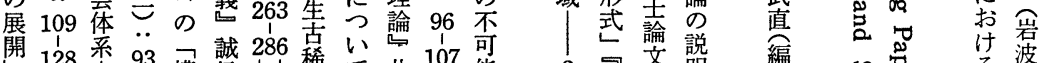

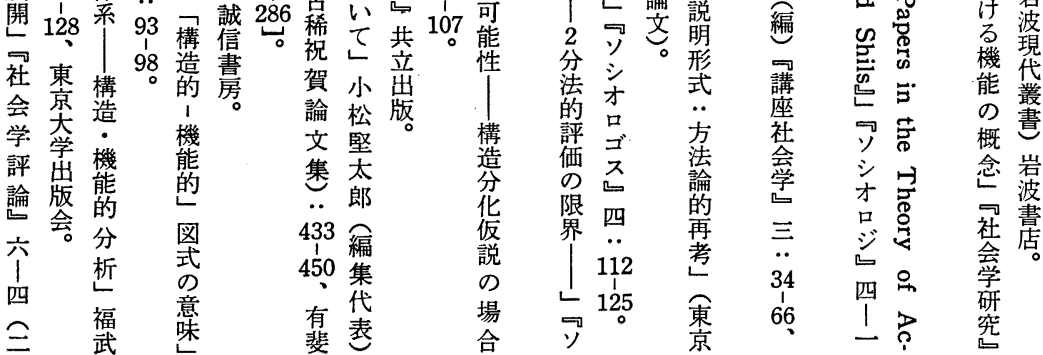

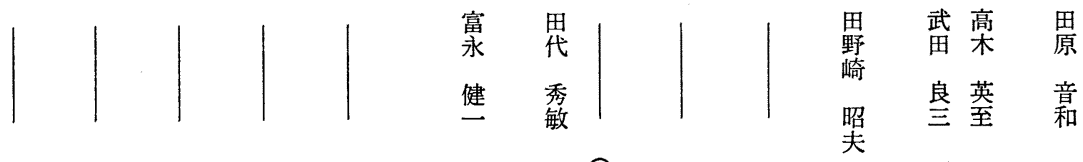

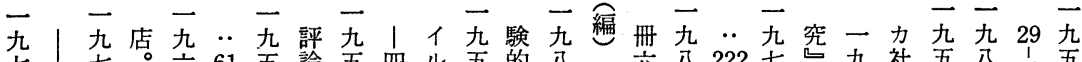

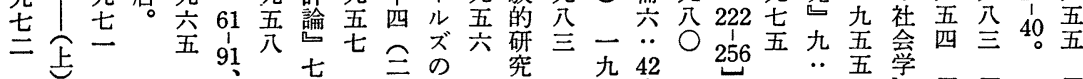

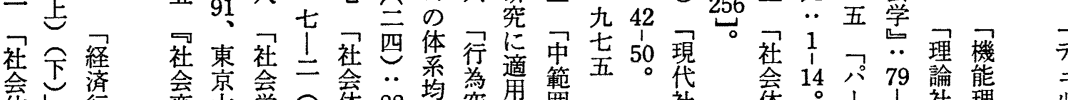

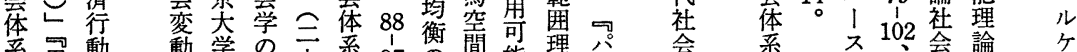

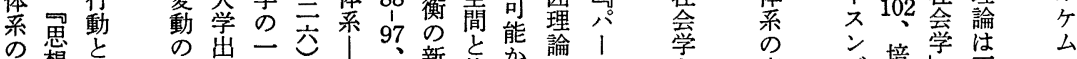

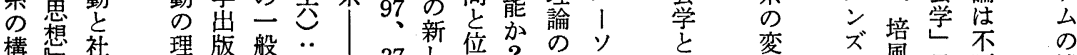

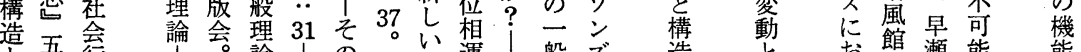

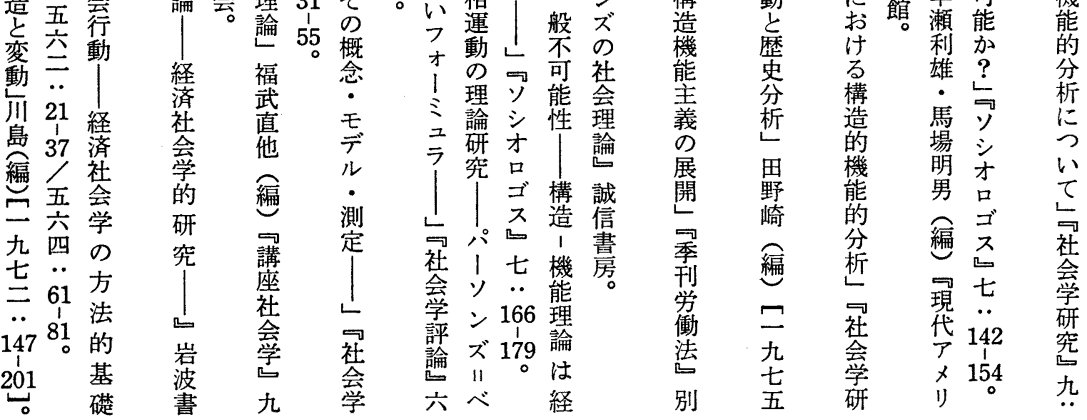




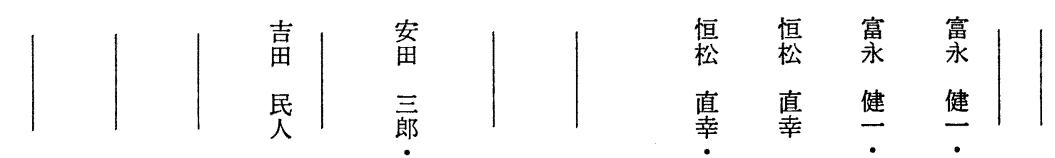

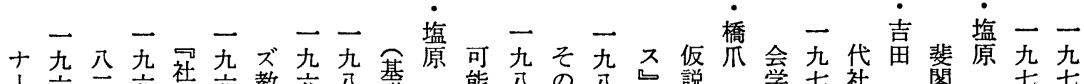

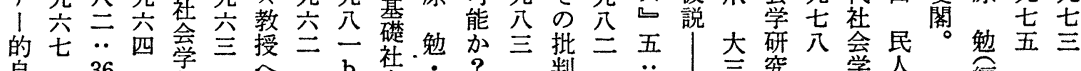

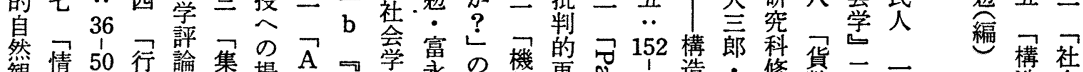

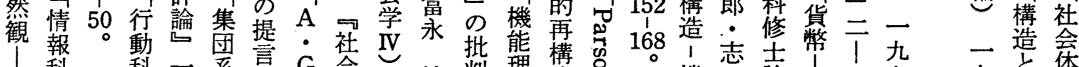

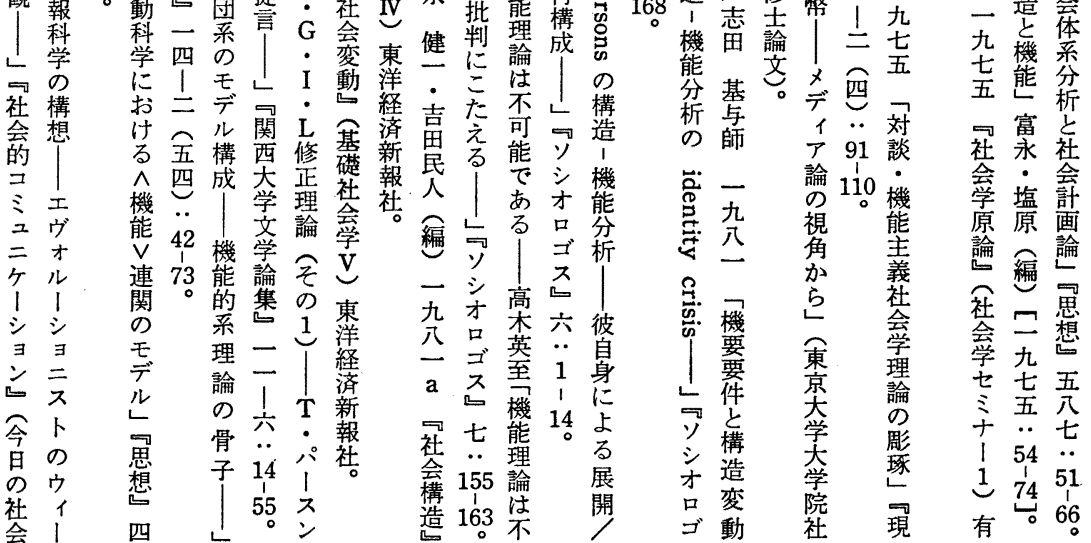

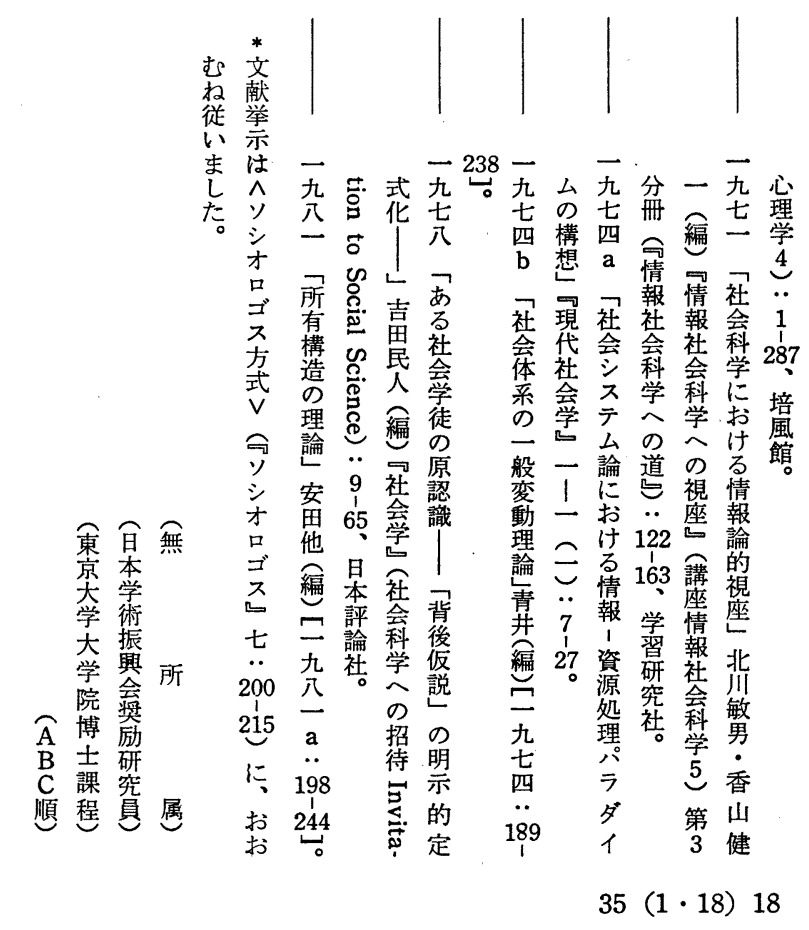




\section{Structural-Functional Analysis at a Crisis}

- Its developments in Japan, problems and some conclusions -

\section{Daisaburo Hashizume \\ Kiyoshi Shida \\ Naoyuki Tsunematsu \\ (Alphabetical Order)}

Structural-functional analysis in sociology stemmed from Talcott Parsons. Yet the ambiguity and obscurity of his idea evoked various criticisms. Japanese sociologists had not only accepted this idea but also its criticisms. Among these sociologists, Ken'ichi Tominaga, Tamito Yoshida, and Naoki Komuro have made important contribution, in an effort to overcome the criticisms, to the refinement of structural-functional analysis. These three agreed upon the formulation that the functional requisites evaluate and control social structures.

Following this formulation the authors have constructed the model idealistically representing structural-functional analysis. This construction aims to evaluate structural-functional analysis from the viewpoint of scientific methodology in general.

Our analysis has revealed two critical defects of the logical structure of structural-functional analysis. Specifically, the plurality of functional requisites leads to the indeterminacy of their control over and evaluation of social structures. And the concept of functional requisite becomes redundant in deriving the hypotheses of structural change of social system. We conclude that there is no room to avoid the above difficulties in the formulation of structural-functional analysis. Therefore, this theoretical attempt has no future.

\section{The Explanation on Structural-Functionalism and Their Testability}

\section{Atsushi Naoi \\ Osaka University}

Today, the Structural-Functionalism in the sociological field is faced with the critical difficulties. On this paper, I examine the three reasons of those difficulties.

First, the methodological fallacies of the strategy of theory construction by Prof. Parsons'.

Second, the impossibility of the structural-functional theory as the complete 